\title{
Ekonomik Gelişmişliğin Göçler Üzerindeki Etkisi: Denizli Örneği
}

\author{
The Effect of Economic Development on the Migrations; Case of Denizli
}

\author{
İbrahim GÖKBURUN \\ Dr. Öğr. Üyesi, Pamukkale Üniversitesi, \\ Fen - Edebiyat Fakültesi, Coğrafya Bölümü, \\ igokburun@pau.edu.tr \\ https://orcid.org/0000-0003-3007-0010
}

Makale Başvuru Tarihi: 13.12.2019

Makale Kabul Tarihi: 28.12.2019

Makale Türü: Araştırma Makalesi

\section{Anahtar}

Kelimeler:

$G \ddot{c}$,

Sanayi,

Denizli,

Keywords:

Migration,

Industry,

Denizli,

\section{ÖZET}

Bu çalışmada, Denizli'de 1980-2018 dönemi göçlerin yön ve dağllımına etki eden faktörlerin ekonomik gelişmiş̧lik durumu ve sanayileşme verileri esas alınarak ortaya konulması amaçlanmıştır. Göç, iki nokta arasındaki şartlara bağll olarak ortaya çıkan bir tercih durumudur. Türkiye'de nüfus doğudan batıya, iç kesimlerden klyllara doğru gö̧ etmektedir. Hem gö̧ alan hem gö̧ veren illerden biri olan Denizli; Türkiye'de içgöçlere ilişkin önemli bilgiler sunmaktadır. Araştırmanın temel veri kaynağı, Türkiye İstatistik Kurumu (TÜIK) 1980-2018 dönemi daimi ikametgâha göre içgöç verileridir. Göçlerin yönü ve miktarını belirleyen etkenlerin analizinde; Denizli Sanayi Odası (DSO) üye sayısı, işyeri sayısı, istihdam edilen nüfus miktarı, ithalat, ihracat verileri esas alınmıştır. Ayrıca, Illlerin ve Bölgelerin Sosyo-Ekonomik Gelişmişlik (SEGE) Sıralaması göz önünde bulundurulmuştur. TÜIK, DSO ve Kalkınma Bakanlığı'nın yayınlamış olduğu veriler derlenerek sayısal tablo formatına dönüşürrülmüş̧ür. Bu veriler ArcGIS ortamına aktarılarak dönemsel net göç haritaları oluşturulmuştur. 1980'li ylllara kadar göç veren Denizli; 1985 itibariyle göç alan iller kategorisine geçmiştir. 2008-2018 döneminde ise alınan göçlerle birlikte verilen göçler de artmıştır. Göç olgusunu coğrafi bakış açısıyla irdeleyen Lee'nin 'İtme-Çekme Modeli'ne göre Denizli'de gö̧clerin çekim noktasi sanayileşmedir. Ancak ekonomik dalgalanmalar, göçleri pozitif veya negatif olarak yönlendirmekte ve miktarını belirlemektedir. Mesela 2008 yılında 601 olan net göç miktarı; 2009 yılında 1587'ye düşmüşür. 2008 yllında istihdam edilen nüfus 140.506 iken; 2009 yllında 134.898'e düşmüşı̈̈r. Bu dönemde ithalat, ihracat miktarı da düşmüstür. Denizli'nin göç verdiği iller; SEGE stralamasinda birinci kademe ve ikinci kademe gelişmiş illerde yoğunlaşmıştır. Şehrin göç aldığ iller ise genel olarak üçüncü derecede gelişmiş iller ve diğer alt kademedeki iller kategorisinde bulunmaktadir. Denizli'nin en fazla göç alıp-verdiği iller yakın çevresindeki illerdir. Gelecek dönemde Denizli'de göçlerin yönü ve miktarl; ekonomik gelişmelere bağll olarak şekillenecektir.

\section{ABSTRACT}

This study aims at exploring the factors that affect the direction and distribution of migration in Denizli during 1975-2018. Migration is a phenomenon of choice that arises from on the conditions between two places. Migration in Turkey tends to occur from east to west, from the interior to the coastline. Denizli, which is one of the cities both receiving and sending migration, sheds light on interprovincial migration in Turkey. The main source of the study is Turkey's Statistics Institute's (TSI) interprovincial migration data related to the permanent residences during 1975-2018. In the analysis of the factors determining the direction and amount of migrations, the number of members of Denizli Chamber of Industry (DSO), the number of establishments, population employed, import and export data were taken as basis. Socio-Economic Development (SEGE) Ranking of Provinces and Regions was also taken into consideration. The data published by TSI, DSO and Ministry of Development were compiled and converted into digital table formats. Periodic net migration maps were created by transferring these data to the ArcGIS environment. Denizli, which was a migration-sending city in 1980, moved to the category of cities receiving migration in 1985. In the period of 2008-2018, the migrations to the city increased while the number of people leaving the city also increased. According to Lee's 'Push-Pull Model, which examines the phenomenon of migration from a geographical point of view, industrialization is the pull point of migration in Denizli. However, economic fluctuations direct and determine migrations positively or negatively. For instance, the net migration rate in 2008 which was 601 decreased to -1587 in 2009. The population employed in 2008 was 140,506 while it decreased to 134,898 in 2009. During this period, the number of imports and exports decreased as well. The provinces to which Denizli gave migration in the SEGE ranking are agglomerated as the first and second tiers in the developed provinces. The provinces where the city received migration are generally in the category of third-level developed provinces and other sub-provinces. Immigration and migrations of Denizli mostly happen with near the provinces. The provinces which Denizli heavily received and sent migration are clustered in the neighboring. The direction and amount of migration in Denizli will be shaped by the economic conditions in the future. 


\section{GIRISS}

İnsanlık tarihi kadar uzun bir geçmişe sahip olan göçler, günümüz dünyasının en önemli meselelerinden biridir. İnsanlar, yüzyıllar boyunca savaş, ticaret, yiyecek, içecek, giyecek, barınak ve diğer yaşam malzemelerini sağlamak amacıyla yaşadığı bölgeden farklı bölgelere göç etmiştir. Günümüz dünyasında göç; nedenleri, amaçları ve sonuçları bakımından oldukça karmaşık bir hal almıştır. Göç olgusu; coğrafya, sosyoloji, demografi, ekonomi, antropoloji, tarih, psikoloji, şehir planlama, siyaset bilimi ve diğer bazı ilgili disiplinler tarafindan ele alınan İnterdisipliner bir araştırma alanıdır (Yalçın 2004:3; İçduygu ve Sirkeci, 1999:249). Göç kavramı, farklı disiplinler tarafından farklı şekillerde tanımlansa da bütün tanımların insan, mekân ve zaman ilişkisine odaklandığı görülmektedir.

Göç olgusuna kuramsal bir perspektif kazandıran Lee, (1969:285) göç kavramını yaşanan yerin kalıcı ya da yarı kalıcı olarak değiştirilmesi şeklinde tanımlamamıştır. Göç; insanların ekonomik, toplumsal siyasal veya farklı nedenlerle devamlı yaşama bölgelerinden başka bir yere yapmış oldukları kısa, orta veya uzun süreçli, belli bir süre sonra geriye dönüşü veya sürekli yerleşimi amaçlayan coğrafi, toplumsal ve kültürel bir yer değiştirme hareketidir. Bu yer değişimi kıtalararası, uluslararası, bölgelerarası, kırdan şehre ya da şehirden şehre doğru herhangi bir ölçek veya yönde meydana gelebilir. Zorunlu veya gönüllü olarak gerçekleştirilen göç hareketi; kişisel, aileler ve gruplar şeklinde; geçici veya sürekli olabilir (Göç Terimleri Sözlüğü, 2009:22; Lewis, 1982:15; Doğanay, 1994:165; Yalçın, 2004:13; Özgür ve Yasak, 2009:40; Tümertekin ve Özgüç, 2017:289). Türkiye göç alan, göç veren ve göçlerin transit geçiş güzergâhında olması nedeniyle göç araştırmalarında önemli bir yere sahiptir. Ayrıca, ülkede yoğun şekilde içgöç hareketliği yaşanmaktadır. Denizli, hem göç alan hem göç veren bir il olarak Türkiye'de yaşanan iç göçlere ilişkin önemli bilgiler sunmaktadır.

Türkiye'de iç göç meselesine odaklanan çalışmalar, 1950 sonrasında başlamıştır. İç göçle ilgili araştırmalara bakıldığında; Darkot, 1954; Darkot, 1961; Tümertekin, 1968; Yasa, 1968; Tümertekin, 1972; Yener, 1977; Tümertekin, 1977a; Tümertekin, 1977b; Tekeli ve Erder, 1978; Eraydın, 1981; Doh, 1984; Gedik, 1985; Erel, 1985; Ertürk, 1985; Doğanay, 1986; Cerit, 1986; Algan, 1988; Tandoğan, 1989a; Tandoğan, 1989b ve Erdoğmuş, 1989 göç konusu ele alan literatürdeki ilk çalışmalardır. Göç çalışmaları ve veri kaynaklarının sınırlı olduğu bu süreçte yapılan araştırmalar; Türkiye'de göç literatürünün ilk örneklerini oluşturması açısından oldukça önemlidir. 1950 öncesi dönemi konu alan göç çalışmaları ise genellikle mübadele ve farklı sebeplerle dışarıdan gelen göçlere odaklanmıştır. 1990 sonrasında göçlerle ilgili çalışmalar sınırlı olmakla birlikte ayrıntılı şekilde karşılaştırma ve analiz imkânı sunan verilerin yorumlandığı gözlenmektedir. Türkiye'de göçlerle ilgili verilerin kayıt altına alınmasında 1950-1970 döneminde doğum yeri kriteri esas alınırken; 1975 sonrasında daimi ikametgâh esas alınmıştır. Bu süreçte iç göçle ilgili araştırmalara bakıldığında; Kocaman ve Bayazıt, 1993; Yavuz, 1994; Gedik, 1994; Özgür, 1995; Oktik, 1997; Tekeli, 1997; Akşit, 1998; İçduygu ve Ünalan, 1998; Tekeli, 1998; Sirkeci ve Aydıngün, 1998; İçduygu vd., 1998; Özgür, 1999; Yamak ve Yamak, 1999; Peker, 1999; Akşit, 1999. Bu dönemde göçle ilgili verilerin niceliği çalışmaların içeriğini zenginleştirmiştir. 2000 sonrası dönemde iç göçle ilgili araştırmalar gerek veri kaynakları gerekse nicelik bakımından oldukça zenginleşmiştir. Göç olgusuyla ilgili mevcut araştırmalardan bazıları: Üçdoğruk, 2002; Mutluer, 2003; Gür ve Ural, 2004; Yalçın, 2004; Şensoy, 2005; Çelik, 2005; Çelik, 2006; Yüceşahin ve Özgür, 2006; Apan, 2006; Sağlam, 2006; Özdemir, 2006; Pazarlığlu, 2007; Toroğlu, 2007; Kocaman, 2008; Yakar, 2009a; Yakar, 2009b; Işı1k, 2009; Yakar, 2010; Bülbül ve Köse, 2011; Çiftçi, 2011; Yakar, 2012; Koçak ve Terzi, 2012; Özdemir, 2012; Yakar, 2013; Kocaman, 2014; İnç, 2014; Çelik ve Güven, 2014; Elmastaş ve Y1lmaz, 2015; Yakar, 2015; Peker, 2015; Sertkaya Doğan, 2015; Bahçalı ve Kahraman, 2016; Küçükali, 2016; Gökburun, 2017 ve Yakar, 2017'dir.

Türkiye'de göç olgusunu ele alan araştırmalar giderek yaygınlaşmaktadır; ancak Denizli ilini konu alan müstakil göç araştırmaları oldukça sınırlıdır. Konuyla ilgili Aygören, Gümüşçü ve Uğur (2006) tarafından kaleme alınan "Daimi İkametgâha Göre Türkiye İç Göçlerinde Denizli İlinin Yeri (1980-2000)" adlı çalışmada; 1980-2000 döneminde yaşanan göçler ele almıştır. Çalışmada, 1980 yılına kadar göç veren bir konumda olan Denizli’nin göç alan iller kategorisine geçtiği vurgulanmıştır. Bu durumun temel nedeni 1973 sonrasında sanayi alanında yaşanan gelişmelere ve iş imkânlarına bağlanmıştır. Denizli'nin gelecekte göç almayı sürdüreceği vurgulanmıştır. Denizli'de yaşanan göçleri İstanbul'a odaklanarak irdeleyen Şahin (2005) "İstanbul'a Olan İç Göçlerde Denizli İlinin Yeri ve Göçle Gelen Nüfusun Özellikleri" adlı çalışmada; İstanbul'un iller bazında aldığı göçlerde Denizli'nin oranın düşük olduğunu vurgulanmıştır. Denizli' den İstanbul'a göç eden nüfusun dokuma, tekstil ve kuyumculuk sektöründe etkin olduğu belirtilmiştir. Mutluer (2003) "Uluslararası Göçler ve Türkiye" adlı eserinde Denizli ili Tavas ilçesinde kurumsal ve ampirik bir alan araştırmasıyla göçleri ele almıştır. Göç sorunsalı üzerine kuramsal çerçeve oluşturarak; Tavas ilçesinde iç göçler ve dış göçleri analiz eden Mutluer; 
Tavas örnekleminde yurtdışı iş gücünün sosyoekonomik özelliklerine odaklanmıştır. Keleş, (2007) tarafindan yapılan "1923-1945 Yılları Arasında Denizliye İç ve Dış Göçler" adlı çalışmada ise 1950 öncesi göçler ele almıştır. Ünlütürk Ulutaş ve Kamber (2016) "Iç Göç ve Mekânsal Dışlanma" adlı çalışmada; göç ve mekânsal dışlanma ilişkisini Denizli örnekleminde irdelenmiştir. Araştırmada, 1990 öncesi Denizli’ye göç edenlerin toplumsal uyum ve entegrasyon olanaklarına kavuştuğu; 1990'lı yıllardan sonra göç edenlerin sosyal dışlanma yaşadığı vurgulanmıştır. Ayrıca, Uslu, 2012; Güzel, 2013; Torlak, 2006; örneğinde olduğu gibi bazı çalışmalarda Denizli'de göçlerin sosyolojik boyutunu ele alınmıştır.

Denizli ilinde göçleri ele alan müstakil çalışmalar sınırlı olsa da Denizli tarih boyunca nüfusun hareketli olduğu şehirlerden biridir. Farklı medeniyetlerin izlerini taşıyan Denizli'nin tarihi mirası, bölgedeki nüfus hareketlerine dair bilgiler sunmaktadır. Kalkolitik dönemden günümüze Hitit, Frigya, Lidya, İonya, Roma, Bizans, Selçuklu ve Osmanlı medeniyetlerinin hâkimiyet kurduğu Denizli'de hemen her dönemde yoğun bir nüfus hareketliliği yaşanmıştır. Uygun iklim şartları, ulaşım imkanalrı zengin doğal kaynaklarıyla cazibe merkezi olan Denizli; geçmiş̧en günümüze farklı sebeplerden kaynaklanan göçlere sahne olmuştur. Ancak tarihin hiçbir döneminde günümüzdeki nüfus miktarına ulaşmamıştır.

Osmanlı Döneminde ilk modern nüfus sayımı olan 1831 Nüfus Sayımında Denizli’nin nüfusu 22.323 kişidir (Karal, 1997:206; Kodal, 2014:33). 1893 yılında ise nüfus 212.493 kişidir (Karpat, 2003:162). 1908 yılında Denizli'nin nüfus miktarı 251.122 kişiye yükselmiştir (Kodal, 2014:40). Cumhuriyet döneminde 1927'de yapılan ilk nüfus sayımında 243.817 kişi olan nüfus, 1970 yılında 511.160 kişiye çıkmıştır. 1927-1975 yılları arasını kapsayan 43 yıllık süreçte Denizli nüfusu ikiye katlanmıştır. 2000 yılında 850.029 kişiye yükselen şehrin nüfusu 2018 yılında 1.027.782'ye yükselmiştir 1975-2018 yılları arasını kapsayan 43 yıllık süreçte Denizli'nin nüfusu bir kez daha ikiye katlanmıştır. 2050 yılında ise Denizli'de nüfusun 1.303 .029 kişiye ulaşılacağı tahmin edilmektedir (Tablo 1). Denizli ilinde toplam nüfus miktarı sadece 1935-1940 döneminde 693 kişi azalmıştır. 1940 yılından günümüze ilin toplam nüfusu kararlı ve istikrarlı bir şekilde artmıştır.

Tablo 1. Denizli İlinde Nüfusun Gelişimi

\begin{tabular}{|c|c|c|c|c|c|c|c|c|c|}
\hline Yll & $\begin{array}{c}\text { Toplam } \\
\text { Nüfus }\end{array}$ & $\begin{array}{c}\text { NAH } \\
(\%)\end{array}$ & $\begin{array}{c}\text { Kentsel } \\
\text { Nüfus }\end{array}$ & $\begin{array}{l}\text { Kırsal } \\
\text { Nüfus }\end{array}$ & Yll & $\begin{array}{l}\text { Toplam } \\
\text { Nüfus }\end{array}$ & $\begin{array}{c}\text { NAH } \\
\text { (\%) }\end{array}$ & $\begin{array}{c}\text { Kentsel } \\
\text { Nüfus }\end{array}$ & $\begin{array}{l}\text { Kirsal } \\
\text { Nüfus }\end{array}$ \\
\hline 1927 & 245.048 & - & 41.209 & 202.038 & 2007 & 907.325 & 9.62 & 735.988 & 171.337 \\
\hline 1935 & 285.918 & 19.91 & 43.866 & 242.052 & 2008 & 917.836 & 11.58 & 761.393 & 156.443 \\
\hline 1940 & 285.225 & -0.49 & 47.619 & 237.606 & 2009 & 926.362 & 9.28 & 770.630 & 155.732 \\
\hline 1945 & 315.934 & 20.45 & 51.251 & 264.683 & 2010 & 931.823 & 5.89 & 778.209 & 153.614 \\
\hline 1950 & 340.277 & 14.85 & 61.297 & 278.980 & 2011 & 942.278 & 11.21 & 791.069 & 151.209 \\
\hline 1955 & 368.294 & 15.82 & 72.170 & 296.124 & 2012 & 950.557 & 8.78 & 802.755 & 147.802 \\
\hline 1960 & 425.449 & 28.85 & 100.916 & 324.583 & 2013 & 963.464 & 13.67 & 963.464 & - \\
\hline 1965 & 463.369 & 17.08 & 117.739 & 318.630 & 2014 & 978.700 & 15.81 & 978.700 & - \\
\hline 1970 & 511.160 & 19.63 & 141.309 & 369.851 & 2015 & 993.442 & 15.32 & 993.442 & - \\
\hline 1975 & 560.916 & 18.58 & 171.586 & 389.330 & 2016 & 1.005 .687 & 12.32 & 1.005 .687 & - \\
\hline 1980 & 603.338 & 14.58 & 205.938 & 397.400 & 2017 & 1.018 .735 & 12.92 & 1.018 .735 & - \\
\hline 1985 & 667.478 & 20.21 & 248.673 & 418.805 & 2018 & 1.027 .782 & 8.88 & 1.027 .782 & - \\
\hline 1990 & 750.882 & 23.55 & 337.793 & 413.089 & 2020 & $1.130 .999^{1}$ & - & - & - \\
\hline 2000 & 850.029 & 14.40 & 413.914 & 436.115 & 2050 & 1.303 .029 & - & - & - \\
\hline
\end{tabular}

Kaynak: 1927-2000 genel nüfus sayımları ve ADNKS (url 1).

Denizli'de yıllık nüfus artış hızına bakıldığında, cumhuriyet döneminden günümüze dalgalı bir grafikle karşılaşmaktayız. Nüfus artış hızının en düşük olduğu dönem \%o-0.48 oranıyla 1935 yılıdır. 1955 yılı ise

12020 ve 2050 tahminleri 2027-2018 dönemindeki nüfus verileri esas alınarak aritmetik nüfus artış yöntemi formülü (Ng=Ns+ka.(tg-ts) ile hesaplanmıştır. 
\%028.85 oranıyla nüfus artış hızının en yüksek olduğu dönemdir. 1975 yılında $\% 14.58$ olan yıllık nüfus artış hızı, 1980 yılında \%20.21'e yükselerek \%o6 oranında artmıştır. 1990 y1lında \%023.55'e çıkan yıllık nüfus artış hız1, 2007 yılında \%09.62'ye düşmüştür. 2017 yılında ise \%o12.92'ye yükselmiştir (Tablo 1). Türkiye genelinde nüfus artış hızının düştüğü bir dönemde, Denizli ilinde nüfus artış hızının yükselmesinin nedeni şehrin diğer illerden aldığı göçlerden kaynaklanmıştır.

Denizli'de nüfusun kır-kent dağılımına bakıldığında; 1927 yılında nüfusun \%83'ü kırda, \%17'si kentte yaşamaktadır. Bu dönemde bir kasaba görünümünde olan Denizli'de kentleşme 1980'li yıllarda hızlanmıştır. 1980 'de nüfusun \%66'sı kırda \%34'ü kentte yaşamaktadır. Kentsel nüfus, kırsal nüfusa paralel olarak artsa da 2000 yılına kadar kırsal nüfus daha fazladır. 2000 yılında Denizli'de kırsal nüfus miktarı, kentsel nüfustan 22.198 kişi fazladır. 2007 yılında ise şehir nüfusu 735.988 kişiye çıkarken, kırsal nüfus 171.337 kişiye düşmüştür (Tablo 1). 2012 tarih ve 6360 Sayılı Kanun nedeniyle TÜİK verilerinde 2013-2018 dönemi kırsal nüfus miktarı açıklanmamaktadır. Ancak kırdan kentlere göçler nedeniyle Denizli'de kırsal nüfusun giderek azaldığı gözlenmektedir.

Türkiye'de yarım yüzyılı aşkın bir süredir doğudan batıya, iç kesimlerden kıyılara doğru bir göç akışı yaşanmaktadır. $\mathrm{Bu}$ durumun temel nedeni bölgeler arasındaki gelişmişlik seviyesi ve ekonomik büyüme farklılığından kaynaklanmaktadır (Yakar, 2013:39). Türkiye'de göçlerin giderek yaygınlaştığı 1980 sonrasında Denizli göçlerin çekim merkezlerinden biri olmuştur. İlin komşuları Afyonkarahisar, Uşak ve Burdur yoğun bir şekilde göç verirken Denizli'nin hangi fonksiyonları göçün çekim noktası olmuştur? Denizli'de göçlerin yönü ve miktarın belirleyen etkenler nelerdir?

\section{VERİ VE YÖNTEM}

Bu çalışmada, Denizli'de 1975-2018 dönemi göçlerin yön ve dağılımına etki eden faktörlerin ortaya konulması amaçlanmıştır. Günümüz dünyasında göçlerin sebep ve sonuçları çok katmanlı ve karmaşık bir şekle bürünmüştür. Göç olgusunun sebep ve sonuçlarını çözümlemek amacıyla birçok 'göç kuramı/teorisi' ortaya konulmuştur. Çalışmamızın temel problematiği açısından göç kuram ve modelleri arasında "İtme-Çekme Teorisi' esas alınmıştır. Ravenstein'ın 1885'te ortaya koyduğu “Göç Yasaları Teorisi” bu alanda ilk kapsamlı teorik çalışmadır. Ravenstein'ın teorisine atıfta bulunarak “İtme-Çekme Teorisi” geliştiren E.S. Lee göç literatüründe önemli bir kavramsal çerçeve oluşturmuştur (Ravenstein,1885: 198-199; Ravenstein,1889:241305; Lee, 1969:282-287; Lewis, 1982:22; Stouffer, 1940:845-846; Yalçın, 2004:22). Toplulukları doğdukları ve belli bir süre yaşadıkları yerden kopmaya ve uzaklaşmaya zorlayan çevresel, ekonomik ve toplumsal şartlar göçün itici etkenlerini oluşturmaktadır. Çekici etkenler ise toplulukları belli bir coğrafi alana cezbeden iktisadi ve sosyal şartlardır (Tümertekin ve Özgüç, 2017:311, Doğanay, 1994:168, Yalçın, 2004:114). Ravenstein ile başlayan ve günümüzde giderek genişleyen göç literatüründeki hemen her çalışma; göç olgusunun gelişmiş ve az gelişmiş bölgeler arasındaki nüfus hareketleri olduğu vurgulanmıştır (Yakar, 2013: 28). Bu çalışmada, Denizli'de 1980-2018 dönemi göçlerin yön ve dağılımına etki eden faktörlerin ekonomik gelişmişlik durumu ve sanayileşme verileri esas alınarak ortaya konulması amaçlanmıştır.

Bilindiği üzere Türkiye'de göç hareketlerine dair karşılaştırma ve analiz yapma imkânı sunan sayısal veriler; 1975 y1lı itibariyle ortaya konulmuştur. 1980-2018 dönemi Denizli’de göçler, çok geniş kapsamlı bir konu olması nedeniyle bir makalenin çerçevesini aşmaktadır. Bu nedenle çalışmada genel olarak net göç verilerine odaklanılarak analizler yapılmıştır. Herhangi bir yerleşim yerinin aldığı göçler ile verdiği göçler arasındaki fark net göç olarak tanımlanmaktadır. Bahsedilen yerde alınan göç, verilen göçten fazla ise net göç pozitif; alınan göç verilen göçten az ise net göç negatif yönlüdür (Mutluer, 2003:11). Denizli ilinde alınan göçler, verilen göçler ve net göç durumuna ilişkin veriler derlenerek sayısal tablo formatına dönüştürülmüştür. Bu tablolardaki veriler irdelendiğinde Denizli'de göçlerin 10-15 ilde yoğunlaştı görülmüştür. Bu nedenle araştırmamızda en fazla göç alınan ilk 10 il ve en fazla göç verilen ilk 10 ilin verileri tablolarda ayrıntılı olarak işlenmiştir. Tabloda isim isim gösterilemeyen illerin verileri ise 'diğer iller' adı altında toplanarak tek bir sütunda gösterilmiş̧tir. Söz konusu bu veriler, ArcGIS veri düzlemine aktarılarak ait net göç haritaları oluşturulmuştur. Hazırlanmış olan bu haritalar, konuyla ilgili literatür taramalarından elde edilen verilere ve araştırma sahasındaki gözlemlere dayandırılarak yorumlanmıştır.

Türkiye İstatistik Kurumu (TÜIK) ve T.C Kalkınma Bakanlığı'nın yayınlamış olduğu veriler çalışmanın temel veri kaynaklarını oluşturmaktadır. Ayrıca, Ekonomik verilerin göçler üzerindeki etkisinin ortaya konulması amacıyla Denizli Sanayi Odası (DSO) tarafından yayımlanan veriler esas alınmıştır. 1980-2000 yılları arasında DSO kayıtlı üye sayıları ve işyeri sayısı dönemler itibariyle sanayileşmenin bir göstergesi olarak değerlendirilmiştir. 2000 sonrasında ise istihdam oranı, ithalat, ihracat miktarı gibi önemli veri kaynakları 
eklenmiştir. Ayrıca, İllerin ve Bölgelerin Sosyo-Ekonomik Gelişmişlik (SEGE) Sıralaması Araştırmaları da göz önünde bulundurulmuştur. 1996-SEGE, 2000-SEGE, 2011-SEGE araştırmalarında Denizli'nin göç alıp göç verdiği iller karşılaştırılarak göçün itici ve çekici faktörleri ortaya konulmuştur.

\section{DENIZLI'DE SANAYİLEŞME SÜRECI VE GÖÇLER}

Cumhuriyet döneminde 1920-1950 yılları arasında sakin bir süreç yaşayan Denizli, 1950 sonrasında göçlerle hareketlenmeye başlamıştır. Ancak 1975-1980 dönemine kadar Denizli göç veren bir il iken; 1980-1985 dönemi itibariyle göç almaya başlamıştır. 1985-2018 yılları arasında Denizli’nin aldığı göçler giderek artmıştır. 20082018 dönemini kapsayan süreçte Denizli hem göç alan hem de göç veren bir ile dönüşmüştür (Tablo 1).

Net göç miktarının negatif olduğu 1975-1980 döneminde, Denizli’nin net göç hızı \%o-5,7’tir. 1990-2000 döneminde ise net göç hızı \% 19,8'e yükselerek en yüksek seviyeye ulaşmıştır. Dönem bazında sonuçları takip etmek ve önceki dönemle karşılaştırmak amacıyla; 2008-2018 dönemini yıllık göç verilerinin bütünleştirilmesiyle elde edilen toplam sonuçta Denizli'nin net göç hızı \%o17,6'ya ulaşmıştır. Ancak 2007-2018 döneminde yıl bazında yayımlanan göç verilerine bakıldığında dalgalı bir grafikle karşılaşmaktayız. Mesela 2007-2008 yılında net göç hızı \%o0,66 iken; 2008-2009 döneminde \%o-1,71'e düşmüştür. 2011-2012 döneminde ise net göç hızı yeniden pozitife dönüşerek \%02,58'e yükselmiştir. Bu süreçte 2014-2015 yılı net göç hızı \%05,27 oranıyla en yüksek olduğu dönemdir. 2016 yılı itibariyle yeniden düşmeye başlayan net göç hızı 2017-2018 döneminde \%o-0,84'e kadar düşmüştür (Tablo 1).

Tablo 2. Denizli İlinde Göçler (1975-2018)

\begin{tabular}{|c|c|c|c|c|}
\hline \multicolumn{5}{|c|}{ 1975-2018 Yılları Arası Dönem Bazında Göç Verileri } \\
\hline Dönem & Aldığğ Göç & Verdiği Göç & Net Göç & Net Göç Hızı (\%o) \\
\hline $1975-1980$ & 26.248 & 29.288 & -3.040 & $-5,7$ \\
\hline 1980-1985 & 31.811 & 29.716 & 2.095 & 3,5 \\
\hline $1985-1990$ & 43.523 & 32.953 & 10.570 & 15,4 \\
\hline $1990-2000$ & 57.412 & 42.207 & 15.205 & 19,8 \\
\hline $2008-2018^{2}$ & 283.227 & 266.076 & 17.151 & 17,6 \\
\hline \multicolumn{5}{|c|}{2008 - 2018 Dönemi Yıl Bazında Göç Verileri } \\
\hline Dönem & Aldığg Göç & Verdiği Göç & Net Göç & Net Göç Hızı (\%o) \\
\hline $2007-2008$ & 22.721 & 22.120 & 601 & 0,66 \\
\hline 2008-2009 & 20.119 & 21.706 & -1.587 & $-1,71$ \\
\hline $2009-2010$ & 21.863 & 23.468 & -1.605 & $-1,72$ \\
\hline $2010-2011$ & 23.454 & 23.853 & -399 & $-0,42$ \\
\hline 2011-2012 & 24.446 & 21.992 & 2.454 & 2,58 \\
\hline $2012-2013$ & 27.088 & 24.039 & 3.049 & 3,17 \\
\hline 2013-2014 & 28.279 & 24.771 & 3.508 & 3,59 \\
\hline 2014-2015 & 30.185 & 24.961 & 5.224 & 5,27 \\
\hline 2015-2016 & 28.170 & 24.794 & 3.376 & 3,36 \\
\hline 2016-2017 & 28.855 & 25.466 & 3.389 & 3,33 \\
\hline $2017-2018$ & 28.047 & 28.906 & -859 & $-0,84$ \\
\hline
\end{tabular}

Kaynak: 1980-2018 dönemi TÜİK göç verileri derlenerek yazar tarafından hazırlanmıştır. 
Göç olayının temelinde insanların geçimlerini sağlamak ya da daha iyi şartlarda yaşamak için daha uygun yerlere gitme ve burada iş bulma, çeşitli imkânlardan faydalanması amaçlanmaktadır (Atalay, 1994:85). Türkiye'de 1950'lerde başlayan sanayileşme ancak 1980'lerde aktif hale gelmiştir. 1950-1980 sürecinde bir anlamda Türkiye'de sanayileşmenin alt yapısı hazırlanmıştır. Sanayileşme, 1980'li yıllarda toplumsal yaşamı değiştirip dönüştürmüştür. Türkiye ekonomisindeki dönüşüm nüfusun kırdan kentlere doğru göç etmesine yol açmıştır. Gelişmemiş bölgelerden daha gelişmiş bölgelere yönelen göçler, 2000'lere doğru giderek yoğunlaşmıştır.

Denizli, Anadolu'da yaşanan ekonomik, siyasi ve toplumsal dönüşüme öncülük eden şehirlerden biri olmuştur. Şehirde özellikle tekstil sektöründeki yatırımlar ön plana çıkmıştır. Tarım ve hayvancılığa bağlı olarak el tezgâhlarında yapılan üretim, şehrin yerleşim tarihi kadar köklüdür. Tekstil üretiminin geçmişi Roma dönemine kadar uzanmaktadır (Erdemir, 2007:25-29).

12. yüzyılın başlarında Ahiler'in Yeşilova civarında kurmuş oldukları tabakhaneler, bölgedeki organize üretimin köklerini göstermektedir. Cumhuriyet döneminde Teşvik-i Sanayi Kanunu'nun etkisiyle Denizli'deki özel girişimciler; tabaklık deri işleme sanayii, tahin, pamuk ve çırçır fabrikaları açmıştır. 1950 sonrasında sanayileşme çabaları yoğunlaşmıştır. 1960'lı yıllarda kurulan iki sanayi çarşısında tekstil atölyeleri bulunmaktadır. Ancak gerçek anlamda sanayileşme 1970'lerde başlamıştır. 1970 sonrasında Denizli sanayisindeki doğal kümelenme yavaş yavaş endüstriyel üretime dönüşmüştür (DSO, 2013:3). Kesintisiz elektrik sağlanması Denizli'de dokuma tezgâhlarının yapısını ve üretim kapasitesini geliştirilmiştir. Üretim teknolojisiyle birlikte pazar alanı ve payı genişlemiştir.

1973-1977 dönemini kapsayan III. Beş Yıllık Kalkınma Planı kapsamında sanayinin gelişmesi amacıyla girişimcilere teşvik imkânı sunulmuştur. Geleneksel dokumacılık faaliyetlerinin yaygın olduğu Denizli'de 1980’li yıllarda fabrikasyon üretime geçilmiştir. El ve yarı otomatik dokuma tezgâhlarında iç pazara yönelik üretim yapan Denizlili girişimciler; 1980'li yıllarda modern sanayi tesisleri kurmaya başlamıştır. (DSO, 2013:3; Batmaz, 2001:8; Karaalp, 2004:172; Denizli Sanayi Odas1 Envanteri, 2003:40). Bu durum Denizli'de sanayinin gelişmesi ve çeşitlenmesini sağlamıştır. 1980'li yıllarda geleneksel dokumacılığı modern sanayi işletmelerine dönüştüren girişimciler; Denizli'yi bir tekstil merkezi haline getirmiştir.

Türkiye iç pazarlarına hatta yurtdışı piyasalara açılan tekstil sektörüne zamanla mermer ve traverten yataklarından elde edilen ürünler eklenmiştir. Dünyaca ünlü Pamukkale travertenleri, bölgedeki şifalı su kaynakları ve tarihi miras şehirde turizm sektörünü canlandırmıştır. Ayrıca, intansif tarım uygulamasıyla tarım ve hayvanc1lık gelişmiştir. Eğitim, sağlık ve hizmet sektöründeki gelişmeler Denizli’nin çevresindeki illere göre bir çekim merkezi olmasını sağlamıştır. İş imkânları nedeniyle Denizli, kırsal alanlardan ve komşu illerden göç almaktadır (Kara, 2008:105; Şanlı ve Kara, 2019:278; Belge, 2018:172).

Denizli'de sanayileşme ve ekonomik veriler, göçlerin yön ve dağılım ilişkisini yansıtan şehirlerden biridir. Ancak 1970-2000 yılları arasında Denizli'de sanayileşmenin boyutlarını ortaya koyacak veriler oldukça sınırlıdır. Denizli Sanayi Odası'na (DSO) kayıtlı üye sayısı 1975-2018 sürecinde periyodik bir şekilde kayıt altına alındığı için göç ve sanayi ilişkisinin kurulması açısından temel veri kaynaklarından birini oluşturmaktadır. Çalışmamızda DSO'ya kayıtlı üye sayısı sanayileşmenin temel göstergelerinden biri olarak değerlendirilmiştir.

1973'te Ege Bölgesi Sanayi Odası'ndan ayrılarak 176 üyeyle kurulan DSO üye sayıs1 1974'te 237'e yükselmiştir. DSO'ya kayıtlı üye sayısı 1982 yılında 419 iken; 1985 yılında üye sayısı 453'e çıkmıştır. 1990 yılında 460 olan üye sayıs1; 2000 yılında 921'e çıkmıştır. Ancak 2007 yılında 1287'ye çıkan DSO üye sayısı, 2008 y1lında 1205'e düşmüsstür. 2010 yılında 1338'e yükselen DSO'ya üye sayısı 2015 y1lında 1329'a düşmüştür (Şekil 1). Kuruluşundan günümüze DSO'ya kayıtlı üye sayısı 2016 yılında 1545'e yükselen en yüksek seviyeye ulaşmıştır. 2017 yılında 1497'ye düşmüştür (DSO, 2013:3; DSO, 2018:174, DSO, 2019:5). 
Şekil 1. Denizli Sanayi Odası Üye Sayısı

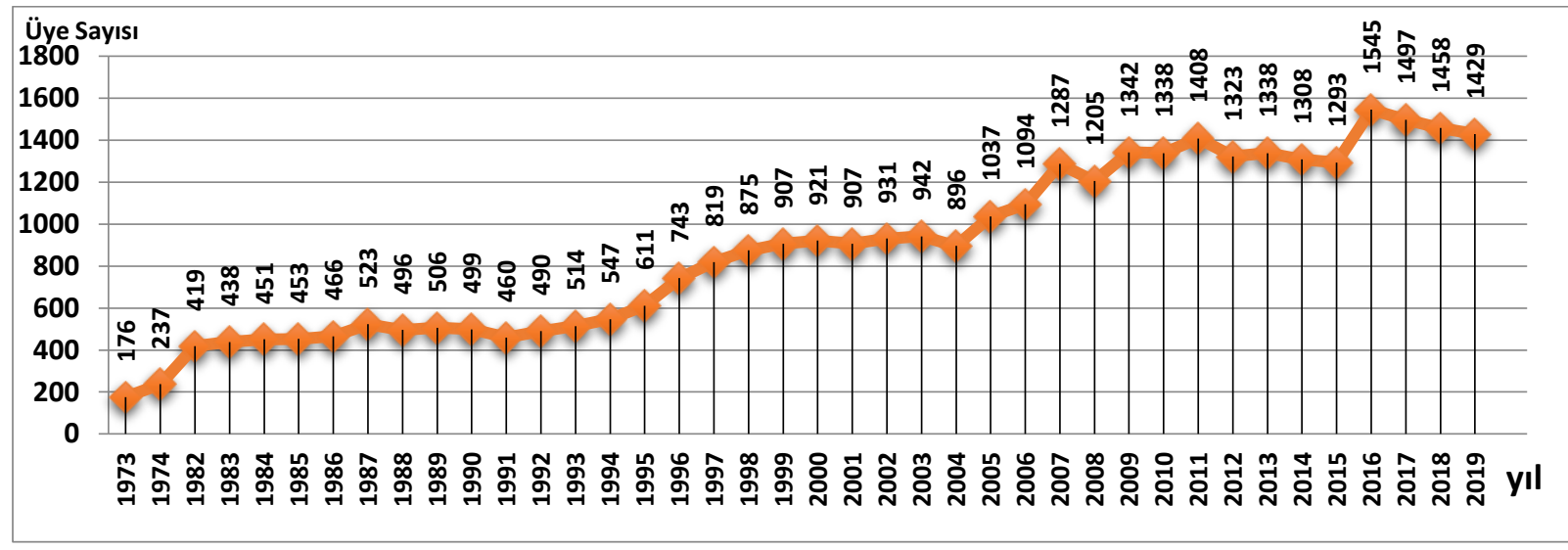

Kaynak: DSO Stratejik Planı 2019-2023 ve DSO, 2013:5.

Denizli'de sanayileşme durumuna bakıldığında; 1980 yılında Denizli'de küçük imalat sanayi işyeri sayısı 4.540 iken; 10 kişi ve üzeri istihdam sağlayan işyeri sayıs1 117 tanedir. Ancak sanayi sektöründe istihdam edilen 12.109 kişilik toplam nüfusun \%68'i büyük imalat sanayi işyerlerinde istihdam edilirken \%32'si küçük imalat sanayi işyerinde istihdam edilmiştir (Temel vd., 2002:9-14). 1980 yılında Türkiye geneli illerdeki işyeri sayısına göre yapılan sıralamada, Denizli 11. sırada yer almıştır. 1996'da Türkiye geneli illerdeki işyeri sayısına göre yapılan sıralamada ise Denizli'de 6. sıraya yükselmiştir. Türkiye geneli toplam imalat sanayi işyerleri içinde, Denizli'nin payı 1980 y1lında \%1,34 iken 1996 y1lında \%3,97'ye yükselmiştir (Temel vd., 2002:13-14). 1985 yılında Denizli'de küçük imalat sanayii işyeri sayısı 4.651 iken; 115 kişi ve üzeri istihdam sağlayan işyeri sayısı 115 olup toplam 4.766 imalat sanayi işyeri bulunmaktadır. 1986 yılında 25 ve üzeri istihdam sağlayan işletmeleri kapsayan sayımda ise sanayi sektöründe istihdam edilen toplam nüfus 9.677 kişi iken; 1989 y1lında 11.746 kişiye yükselmiştir (Aygören vd., 2006:332).

1990 yılında Denizli'de küçük imalat sanayi işyeri sayısı 6.316 iken; 50 ve daha fazla işçi çalıştıran büyük imalat sanayi işyeri sayısı 99 olup toplam 6.415 işyeri bulunmaktadır. 50 ve üzeri istihdam sağlayan işletmelerde istihdam edilen toplam nüfus 12.201 kişidir (Temel vd., 2002:9; DSO, 2019:5). 1996 y1lında Denizli'de 5.923 küçük imalathane işletmesi, 419 tane ise 50 ve üzeri istihdam sağlayan büyük sanayi işletmesi bulunmaktadır. Küçük imalathane işletmesinde çalışan nüfus miktarı 4.626 kişi iken; büyük sanayi işletmesi çalışan nüfus miktarı 28.253 kişidir. Denizli'de mevcut 6.342 işyerinde toplam 32.879 kişi istihdam edilmiştir. Denizli'de istihdamının Türkiye genelindeki oranı 1980 yılında \%0,9 iken; 1996 y1lında \%2,75'e yükselmiştir (Temel vd., 2002:9-45; DSO, 2019:5).

Denizli ilinin Türkiye istihdamı içindeki payı 1980 yılında \%0.61 iken; 1997 yılında \%3,02'ye çıkmıştır (Mutluer, 2003:16) 1996 yılında Denizli'de istihdam edilen toplam 40.756 kişilik nüfusun \%86's1 sanayi sektöründe istihdam edilirken \%14'ü diğer sektörlerde istihdam edilmiştir. 1980-1996 döneminde Denizli'de istihdam edilen nüfus üçe katlamıştır. Ancak küçük ölçekli işletmelerde istihdam oranı ikiye katlanırken; büyük ölçekli işletmelerde istihdam oranı dörde katlanmıştır. Denizli sanayisindeki bu gelişme başta çevre iller olmak üzere göçlerin çekim merkezi olmuştur. 2000 y1lında ise 50 ve üzeri istihdam sağlayan 151 büyük sanayi işletmesinde 33.041 kişi istihdam edilmiştir. 1990 yılında Denizli'de istihdam edilen toplam nüfus miktarı 12.602 kişi iken; 2005 yılında sadece işyeri sayısı 12.287'ye çıkmıştır. Bu sonuç 1990-2005 dönemini kapsayan 15 yıllık süreçte Denizli'de sanayileşmenin yükselişini göstermektedir. 50 ve üzeri iş̧̧i istihdam eden özel firmalar 2012 y1lında toplam 58.290 kişiyi bünyelerinde barındırırken, 2013 yılında bu rakam 67.400'e, 2014 yılında 73.425 'e, 2015 yllında 73.793 yükselmiştir. 2016 yılında ise 75.035 'e ve 2017 y1lında 78.911 'e çımıştır (DSO, 2018:219).

2008 sonrası göçlerin yön ve dağılımın yorumlanmasında; mevcut verilere ithalat, ihracat miktarı gibi yeni veri kaynaklarına eklenmiştir. Denizli'de 2008 yılında 1.634.676 dolar olan ithalat; 2009 y1lında 1.146.484 dolara düşmüştür. Bu süreçte 2011 yılında 2.262.650 doları bulan ithalatın zirve düzeyini oluşturmaktadır. 2015 yılına ithalat 1.902.001 dolara düşmüştür. 2017 yılında ise 2.009.390 dolar bandına çıkan ithalat 2018 y1lında 1.989.330'a düşmüştür. İthalat ve ihracat nmiktarında düşüş yaşansa da Denizli 2017 yılında ülkemizin en fazla ihracat ve ithalat yapan illeri arasında yer almaktadır (Doğan, 2019: 652). Genel olarak bakıldığında ithalat değerinde en keskin düşüş 2009 yılında yaşanmıştır (Tablo 3). 2008-2018 dönemine Denizli'de göç verileri ile ithalat verileri arasında paralel bir ilişki olduğu gözlenmektedir. 
İhracat verilerine bakıldığında Denizli'de 2008 yılında toplam ihracat 2.196 .710 dolara yükselmiştir. 2008 küresel ekonomik krizin etkilerinin hissedilmeye başlandığ 2009 y1lında ihracat değeri 1.587 .500 dolara düşmüştür. 2010 yılında yeniden yükselişe geçen ihracat parametresi 2.127.923 dolara çıksa da 2008 düzeyine ulaşamamıştır. 2015 yılında ihracat 2.516.246 dolara ulaşmıştır. Denizli'de net göç miktarının en yüksek olduğu bu dönemde istihdamın 192.244 kişiye çıkmıştır. Denizli'de ekonomisinde 3.109.370 dolarla ihracat rekorunun kırıldığı 2018 yılında istihdam sayısı 188.845'e düşerken; net göç miktar1 -859'a düşmüştür (Tablo 3).

Tablo 3. Denizli İli'nde 2008-2018 Dönemi Net Göç, İstihdam, İthalat ve İhracat Verileri

\begin{tabular}{|c|c|c|c|c|c|c|c|}
\hline Yıl & Alınan & Verilen & Net Göç & İstihdam & İthalat & İhracat & DSO \\
\hline 2008 & 22.721 & 22.120 & 601 & 140.506 & 1.603 .676 & 2.196 .710 & 1.205 \\
\hline 2009 & 20.119 & 21.706 & -1.587 & 134.898 & 1.146 .484 & 1.157 .500 & 1.342 \\
\hline 2010 & 21.863 & 23.468 & -1.605 & 151.891 & 1.730 .895 & 2.126 .641 & 1.338 \\
\hline 2011 & 23.454 & 23.853 & -399 & 155.030 & 2.262 .295 & 2.639 .582 & 1.408 \\
\hline 2012 & 24.446 & 21.992 & 2.454 & 166.371 & 2.208 .190 & 2.622 .545 & 1.323 \\
\hline 2013 & 27.088 & 24.039 & 3.049 & 171.321 & 2.176 .670 & 2.741 .457 & 1.338 \\
\hline 2014 & 28.279 & 24.771 & 3.508 & 178.417 & 1.771 .478 & 2.815 .481 & 1.308 \\
\hline 2015 & 30.185 & 24.961 & 5.224 & 192.244 & 1.667 .666 & 2.325 .512 & 1.293 \\
\hline 2016 & 28.170 & 24.794 & $3 . .376$ & 187.059 & 2.009 .358 & 2.403 .360 & 1.545 \\
\hline 2017 & 28.855 & 25.466 & 3.389 & 199.999 & 2.009 .358 & 2.677 .119 & 1.497 \\
\hline 2018 & 28.047 & 28.906 & -859 & 188.845 & 1.989 .330 & 3.109 .370 & 1.458 \\
\hline
\end{tabular}

Kaynak: TÜIK ve DSO verileri derlenerek yazar tarafından hazırlanmıştır.

Şekil 1. Denizli İli'nde İstihdam, İthalat, İhracat ve Net Göç İlişkisi

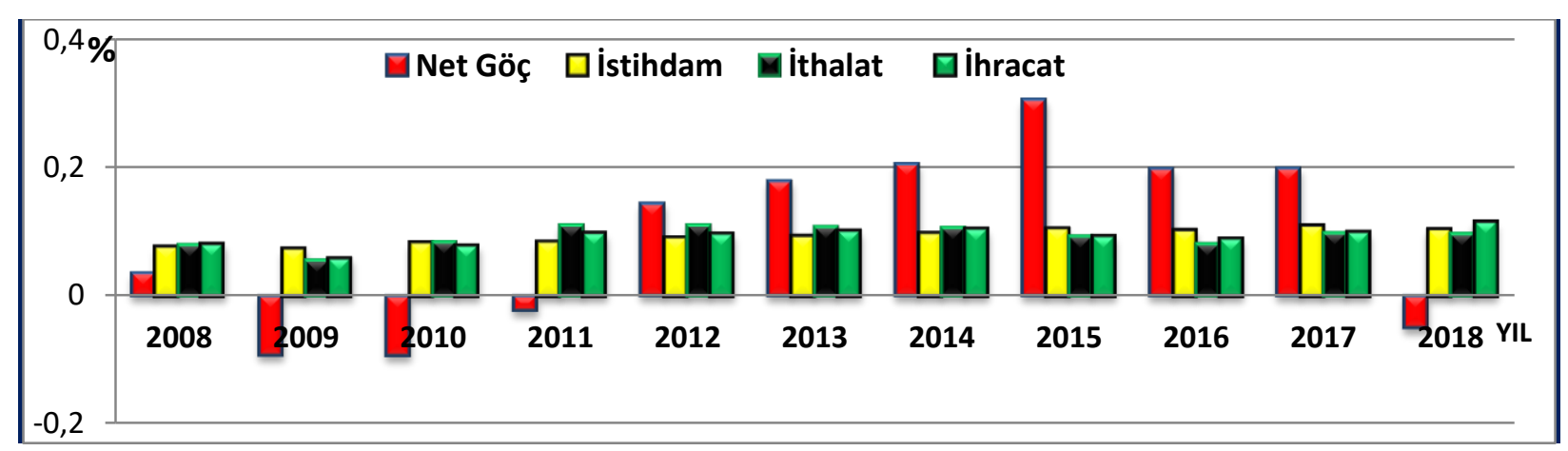

2008-2018 döneminde Denizli'de net göçler dalgalı bir grafik çizmektedir. Bu dalgalanmanın temel nedeni ekonomik etkenlerden kaynaklandığını ortaya koyan önemli veriler bulunmaktadır. Bütün dünya ülkelerini etkileyen 2008 Dünya finansal krizinden göreceli olarak etkilenen ülkelerden biri de Türkiye'dir. Finans temelli bir kriz olan 2008 ekonomik krizi, 1929'da yaşanan Büyük Buhran dâhil, diğer krizlerden oldukça farklı ve dünyada bugüne kadar yaşanan ilk gerçek küresel krizdir. Başta gelişmiş ülke ekonomileri olmak üzere dünya ekonomisi olumsuz etkilemiştir (Öztürk ve Gövdere, 2010:378; Özatay, 2009:22; Engin ve Göllüce, 2016:28). Türkiye'de 2009 yılında reel mal ve hizmet ihracatı \%5,3; ithalat ise \%14,3 oranında daralmıştır. Küresel kriz nedeniyle 2009 'da özel sabit sermaye yatırım harcamaları \%22,3 oranında azalmıştır. Özel yatırım harcamalarındaki düşüşe özel tüketim harcamalarındaki azalma eşlik etmiştir. Firmalar özellikle stoktaki malları piyasaya çıkarmış üretim konusunda gönülsüz davranmış talepteki azalış ve üretimdeki azalışında etkisiyle Türkiye ekonomisi küçülmeye başlamıştır (Engin ve Göllüce, 2016:35).

2008 krizinin Denizli sanayi işletmelerindeki etkilerine bakıldığında; kriz döneminde önemli oranlarda sipariş iptallerinin yaşandığı, işletmelerin çoğunluğunun bir maddi zarara uğradığı, yurt dişına bağımlı çalışan işletmelerin küresel sorunlardan fazlaca etkilenmesi nedeniyle kriz sürecinde işletmeler işçi çıkarmıştır (Okay ve Karahan, 2012:3014-315). İstihdam verileri Denizli'de göçlerin ekonomik durumla bağlantısı bakımından 
önemli bir göstergedir. 2007-2018 döneminde imalat sanayiindeki istihdamın yıllık ortalama dağılımı 186.658 kişidir. 2002 yılında 108.382 kişi olan istihdam miktarı; 2008 yılında 140.506 kişiye yükselmiştir. 2009 yılında ise Denizli'nin toplam istihdam miktarı 134.898 kişiye düşmüştür (Tablo 3).

Denizli'de istihdam edilen toplam nüfus 2010 yllında 152.593 kişi iken; 2012 yılında 173.142 kişiye yükselmiştir. Net göç miktarının en yüksek pozitif değere ulaştığı 2015 yılında Denizli'de istihdam sayısı 192.244 kişidir. İstihdam edilen toplam nüfus 2016 yllında 214.632 kişiye yükselirken; 2017'de istihdam 199.999 kişiye yükselerek Denizli tarihinde zirveye ulaşmıştır. Denizli'de, küresel krizin etkilerinin yaşandığ 1 2008-2009 yıllarında 4/a kapsamındaki sigortalı çalışan sayılarının azalırken; 2010-2017 döneminde sürekli artmıştır (Tablo 3). 2018 yılında ise istihdam edilen kişi sayısı 188.845'e düşmüştür. Bu dönemde Denizli’nin toplam net göç verileri negatif yönlü olup -859'a düşmüştür (Tablo 2). 2002-2018 döneminde Denizli'de istihdam edilen toplam nüfus yaklaşık olarak ikiye katlanmıştır. İthalat ve ihracat verileri ise dalgalı bir grafik çizmektedir. Mesela Denizli'de ihracat değeri 2008 yılında 2.196.710 dolar iken, 2018 yılında 3.109.370 dolara yükselmiştir. 2009 yılı sonrasındaki ihracat rakamlarında ise özellikle döviz kurlarındaki farklar dolayısıyla ihracat düşmüştür. Bu sonuç elbette ki göçlere yansımıştır.

\subsection{Denizli’de Alınan-Verilen Göçlerin Dağılımı}

Türkiye gibi gelişmekte olan ülkelerde, gelir dağılımı ve gelişmişlik düzeyi şehirler ve bölgeler arasında oldukça yüksek farkl1lıklar görülmektedir. Bu durum kırdan şehre, küçük şehirlerden büyük şehirlere doğru akan göçlere yol açmaktadır. 1975-1980 döneminde Denizli 26.248 kişi göç almıştır. Alınan göçlerin \%60'1 10 ilde toplanmıştır. 1980-1985 döneminde sadece aldığı göçler nedeniyle Denizli nüfusu 5.135 kişi artmıştır. Bu dönemde Denizli'nin aldığı toplam göç miktarı 31.811 kişidir. Alınan göçlerin \%62'si 10 ilde toplanmıştır.1985-1990 döneminde Denizli'nin aldığı toplam göç miktarı 43.523 kişidir. Alınan göçlerin \%59'u 10 ilde kümelenmiştir. 1990-2000 döneminde Denizli’nin aldığ toplam göç miktarı 57.412 kişidir. Bu dönemde alınan göçlerin \%63'ü 10 ilde kümeleniştir. 2008-2018 döneminde Denizli'nin aldığı toplam göç miktarı 283.227 kişidir. Alınan göçlerin \%68'i 10 ilde toplanmıştır. 1980-2018 sürecinde beş farklı dönemde Denizli'nin aldığı göçlerin kümelendiği İzmir, Aydın, Afyonkarahisar, İstanbul, Ankara, Burdur ve Muğla illeri; her dönemde ilk 10 il arasında yer almıştır. Burdur, Uşak, Antalya, Manisa, Konya, Erzurum, Ağrı illeri ise farklı dönemlerde Denizli’nin en fazla göç aldığı ilk 10 il arasında bulunmaktadır (Tablo 4).

Tablo 4. Denizi’nin Aldığı Göçler 1975-2018

\begin{tabular}{|c|c|c|c|c|c|c|c|c|c|c|}
\hline Sira & İller & 1975-1980 & İller & 1980-1985 & İller & $185-1990$ & İller & 1990-2000 & İller & 2008-2018 \\
\hline 1 & İzmir & 3.255 & İzmir & 4.397 & Afyonk. & 4.792 & Afyonk. & 7.175 & İzmir & 26.687 \\
\hline 2 & Aydın & 3.066 & Aydın & 3.672 & Aydın & 4.696 & İzmir & 4.581 & Aydın & 25.051 \\
\hline 3 & Afyonk. & 1.829 & Afyonk. & 2.488 & İzmir & 4.028 & Aydın & 4.486 & Afyonk. & 21.952 \\
\hline 4 & Burdur & 1.783 & İstanbul & 1.857 & Burdur & 2.852 & İstanbul & 3.428 & İstanbul & 19.940 \\
\hline 5 & İstanbul & 1.384 & Ankara & 1.746 & İstanbul & 2.265 & Burdur & 2.863 & Muğla & 15.858 \\
\hline 6 & Ankara & 1.341 & Burdur & 1.616 & Ankara & 1.989 & Ankara & 2.509 & Antalya & 15.696 \\
\hline 7 & Ağr1 & 932 & Muğla & 1.592 & Muğla & 1.732 & Manisa & 2.136 & Manisa & 12.667 \\
\hline 8 & Muğla & 932 & Manisa & 890 & Erzurum & 1.205 & Uşak & 2.087 & Ankara & 11.779 \\
\hline 9 & Erzurum & 687 & Ağr1 & 715 & Uşak & 1.193 & Muğla & 1.661 & Burdur & 9.977 \\
\hline \multirow[t]{3}{*}{10} & Uşak & 629 & Uşak & 673 & Ağr1 & 1.059 & Konya & 1.562 & Uşak & 9.117 \\
\hline & Diğer 56 il & 10.410 & Diğger 56 il & 12.165 & Diğer 62 il & 17.712 & Diğer 70 il & 24.924 & Diğer 70 il & 114.503 \\
\hline & İl Sayısı 66 & 26.248 & İl Sayısı 66 & 31.811 & İl Sayısı 72 & 43.523 & İl Sayısı 80 & 57.412 & İl Sayısı 80 & 283.227 \\
\hline
\end{tabular}

Kaynak: 1980-2018 dönemi TÜİK göç verileri derlenerek yazar tarafından hazırlanmıştır.

1975-1980 döneminde Denizli'nin verdiği toplam göç miktarı 29.288 kişidir. Verilen toplam göçün \%62'si 10 ilde toplanmıştır. 1980-1985 döneminde Denizli'nin verdiği toplam göç miktarı ise 29.716 kişiye ulaştır; verilen göçlerin \%65'i 10 ilde kümelenmiştir. 1985-1990 döneminde verilen toplam göç miktarı 32.953 kişi olup verilen göçlerin \%67'si 10 ilde toplanmıştır. 1990-2000 döneminde verilen toplam göç miktarı 42.207 kişiye yükselirken; bu göçlerin \%62'si 10 ilde toplanmıştır. 2008-2018 yıllarını kapsayan 10 yıllık süreçte Denizli'nin verdiği toplam göç miktarı 266.076 kişiye yükselmiştir. Bu dönemde verilen göçlerin \%63'ü 10 ilde 
kümelenmiştir. Denizli'nin verdiği göçlerin kümelendiği iller; İzmir, Aydın, İstanbul, Muğla, Afyonkarahisar ve Ankara illeri 1975-2018 sürecindeki her dönemde ilk 10 il arasında yer almıştır. Manisa, Burdur Uşak, Isparta, Konya ve Trabzon, illeri ise farklı dönemlerde Denizli'nin en fazla göç aldığı 10 il arasında yer almıştır. Denizli'nin en fazla göç verdiği iller ve en fazla göç aldığı illerin genel olarak aynı iller olduğu görülmektedir (Tablo 5).

Tablo 5. Denizi’nin Verdiği Göçler 1975-2018

\begin{tabular}{|c|c|c|c|c|c|c|c|c|c|c|}
\hline Sira & İller & 1975-1980 & İller & 1980-1985 & İller & $1985-1990$ & İller & $1990-2000$ & İller & 2008-2018 \\
\hline 1 & İzmir & 5.078 & İzmir & 4.871 & İzmir & 5.535 & İzmir & 5.095 & İzmir & 28.263 \\
\hline 2 & Aydın & 3.982 & Aydın & 4.583 & Aydın & 4.601 & Aydın & 4.261 & İstanbul & 23.664 \\
\hline 3 & İstanbul & 1.914 & İstanbul & 2.158 & İstanbul & 2.549 & İstanbul & 3.275 & Aydın & 23.189 \\
\hline 4 & Ankara & 1.655 & Muğla & 1.860 & Muğla & 1.920 & Muğla & 3.044 & Muğla & 17.682 \\
\hline 5 & Afyonk. & 1.092 & Ankara & 1.766 & Ankara & 1.782 & Antalya & 2.490 & Antalya & 17.638 \\
\hline 6 & Muğla & 1.044 & Afyonk. & 968 & Antalya & 1.506 & Ankara & 2.450 & Afyonk. & 17.052 \\
\hline 7 & Burdur & 959 & Burdur & 938 & Afyonk. & 1.501 & Afyonk. & 1.764 & Ankara & 13.224 \\
\hline 8 & Konya & 822 & Antalya & 809 & Uşak & 944 & Isparta & 1.288 & Manisa & 10.190 \\
\hline 9 & Trabzon & 799 & Uşak & 681 & Burdur & 936 & Burdur & 1.224 & Burdur & 9.252 \\
\hline 10 & Manisa & 794 & Manisa & 650 & Manisa & 885 & Konya & 1.182 & Uşak & 7.656 \\
\hline & Diğer 56 il & 11.149 & Diğer 56 il & 10.432 & Diğger 62 il & 10.794 & Diğger 70 il & 16.134 & Diğger 23 il & 98.266 \\
\hline & İl Sayısı 66 & 29.288 & İ Sayısı 66 & 29.716 & İl Sayısı 72 & 32.953 & İl Sayısı 80 & 42.207 & İl Sayısı 80 & 266.076 \\
\hline
\end{tabular}

Kaynak: 1980-2018 dönemi TÜIKK göç verileri derlenerek yazar tarafından hazırlanmıştır.

Denizli, yoğun şekilde göç aldığı illere aynı şekilde göç vermiştir. Türkiye'nin göçlerin genellikle İstanbul, Ankara ve İzmir gibi büyük şehre yöneldiği görülmektedir. Denizli'nin göç hareketliğinde Ege Bölgesi'nde İzmir başta olmak üzere Afyon, Muğla ve Burdur, Uşak ön plana çıkmıştır. Waldo R. Tobler'in (1970:236-237) Coğrafyanın Birinci Kanunu (First law of geography) olarak tanımladığı "Her şey her şeyle ilişkilidir fakat yakındakiler uzaktakilere göre birbiriyle daha fazla ilişki içerisindedir" ilkesi Denizli'de göçlerin neden çevre illerde kümelendiğini ortaya koymaktadır. Bir değişkene ait benzer değerler genellikle yakın çevrede ortaya çıkar ve bu durum mekânsal kümeleme oluşturur (Anselin, 1988:8; Anselin, 1992:1).

\subsection{Denizli’de Net Göçlerin Dağılımı}

Göç olgusunun ortaya çıkardığı olumlu ya da olumsuz sonuçların tespit edilmesinde net göç verileri ayrı bir önem arz etmektedir. 1975-1980 döneminde Denizli'de toplam net göç miktarı -3.040 kişidir. Net göçün iller düzeyinde dağılımına bakıldığında, 33 ilde net göç verileri pozitif yönlü iken; 33 ilde ise negatif yönlüdür. Bu dönemde göç veren iller kategorisinde yer alan Denizli’de; pozitif yönlü göçlerin \%69'u Burdur, Ağrı, Afyonkarahisar, Muş, Kars ve Adıyaman illerinden gerçekleşmiştir. Negatif yönlü göçlerin \%68'i İzmir, Aydın, Trabzon, İstanbul, İçel, Kayseri, Bursa ve Tokat illerinde kümelenmiştir.

1980-1985 döneminde Denizli'de toplam net göç miktarı 2.095 kişiye yükselmiştir. Denizli, göç veren iller kategorisinden göç alan iller kategorisine geçmiştir. Net göç durumunun iller düzeyinde dağılımına bakıldığında; 41 ilde net göç verileri pozitif yönlü iken; 25 ilde negatif yönlüdür. Pozitif yönlü göçlerin \%71’i Afyonkarahisar, Burdur, Ağrı, Erzurum, Muş, Manisa, Kars ve Van illerinde kümelenmiştir. Negatif yönlü göçlerin ise \%75'i Aydın, İzmir, Nevşehir, Antalya, İstanbul ve Muğla illerinde kümelenmiştir. 
GÖKBURUN, İbrahim - Ekonomik Gelişmişliğin Göçler Üzerindeki Etkisi: Denizli Örneği

Tablo 6. Denizli İli'nde 1980-2018 Dönemi Net Göç Verileri

\begin{tabular}{|c|c|c|c|c|c|c|c|c|c|c|}
\hline \multicolumn{11}{|c|}{ Pozitif Yönlü Net Göç Verileri (1975-2018) } \\
\hline Sura & İller & 1975-1980 & İller & $1980-1985$ & İller & 1985-1990 & İller & $1990-2000$ & İller & 2008-2018 \\
\hline 1 & Burdur & 824 & Afyonk & 1.520 & Afyonk & 3.291 & Afyonk & 5.411 & Afyonk & 4900 \\
\hline 2 & Ağrı & 806 & Burdur & 678 & Burdur & 1.916 & Burdur & 1.639 & Manisa & 2477 \\
\hline 3 & Afyonk. & 737 & Ağr1 & 546 & Ağr1 & 903 & Şanlıurfa & 1.188 & Aydın & 1862 \\
\hline 4 & Muş & 441 & Erzurum & 367 & Erzurum & 887 & Uşak & 1.066 & Van & 1848 \\
\hline 5 & Kars & 378 & Muş & 243 & Muş & 690 & Manisa & 1.046 & Erzurum & 1823 \\
\hline 6 & Adiyaman & 348 & Manisa & 240 & Konya & 444 & Adana & 591 & Ağrn & 1671 \\
\hline 7 & Adana & 205 & Kars & 233 & Kars & 398 & Diyarbakır & 565 & Uşak & 1461 \\
\hline 8 & Van & 142 & Van & 176 & Van & 334 & Erzurum & 539 & Muş & 1324 \\
\hline 9 & Siirt & 107 & Zonguldak & 161 & Isparta & 278 & Hatay & 507 & Adana & 957 \\
\hline 10 & Malatya & 105 & Kütahya & 150 & Adana & 270 & Konya & 380 & Diyarbakır & 944 \\
\hline 11 & Diğer 23 il & 1.026 & Diğer 31 il & 1.295 & Diğer 50 il & 4.328 & Diğer 52 il & 5.670 & Diğer 46 il & 10.869 \\
\hline & Toplam 33 il & 5.119 & Toplam 41il & 5.609 & Toplam 60 il & 13.739 & Toplam 62 il & 18.602 & Toplam 56 il & 30.136 \\
\hline \multicolumn{11}{|c|}{ Negatif Yönlü Net Göç Verileri (1975-2018) } \\
\hline Sira & İller & 1975-1980 & İller & 1980-1985 & İller & $185-1990$ & İller & $1990-2000$ & İller & 2008-2018 \\
\hline 1 & İzmir & -1.823 & Aydın & -911 & İzmir & -1.507 & Muğla & -1.383 & İstanbul & -3.724 \\
\hline 2 & Aydın & -916 & İzmir & -474 & Antalya & -818 & Antalya & -957 & Antalya & -1.942 \\
\hline 3 & Trabzon & -692 & Nevşehir & -403 & İstanbul & -284 & İzmir & -514 & Muğla & -1.824 \\
\hline 4 & İstanbul & -530 & Antalya & -306 & Muğla & -188 & Isparta & -114 & İzmir & -1.576 \\
\hline 5 & İçel & -530 & İstanbul & -301 & Bursa & -126 & Şırnak & -68 & Ankara & -1.445 \\
\hline 6 & Kayseri & -411 & Muğla & -268 & Kocaeli & -82 & Bilecik & -59 & Eskişehir & -609 \\
\hline 7 & Bursa & -353 & Adana & -149 & Manisa & -37 & Bursa & -51 & Isparta & -522 \\
\hline 8 & Tokat & -348 & Bursa & -144 & İçel & -35 & Erzincan & -47 & Bursa & -366 \\
\hline 9 & Ankara & -314 & Adiyaman & -79 & Batman & -33 & Karaman & -40 & Çanakkale & -355 \\
\hline 10 & Zonguldak & -302 & Balıkesir & -75 & Şırnak & -27 & Kars & -39 & Kocaeli & -245 \\
\hline 11 & Diğer 23 il & -1.940 & Diğer 15 il & -404 & Diğer 2 il & -22 & Diğer 8 il & -125 & Diğer 8 il & -377 \\
\hline & Toplam 33 il & -8.159 & Toplam 25 il & -3.110 & Toplam 12 il & -3.169 & Toplam 18 il & -3.397 & Toplam 24 il & -12.985 \\
\hline \multicolumn{11}{|c|}{ TOPLAM NET GÖÇLER MİKTARI (2008-2018) } \\
\hline & Toplam & -3.040 & Toplam & 2.095 & Toplam & 10.570 & Toplam & 15.205 & Toplam & 17.151 \\
\hline
\end{tabular}

Kaynak: 1980-2018 dönemi TÜİK göç verileri derlenerek yazar tarafından hazırlanmıştır.

1985-1990 döneminde Denizli'de toplam net göç miktarı 10.570 kişiye yükselmiştir. Bir önceki döneme göre Denizli’nin net göç miktarı 8.475 kişi artmıştır. Net göç durumunun iller düzeyinde dağılımına bakıldığında; 60 ilde net göç verileri pozitif yönlü iken; 12 ilde negatif yönlüdür. Pozitif yönlü göçlerin \%71'i Afyonkarahisar, Burdur, Ağrı, Erzurum ve Muş, illerinde kümelenmiştir. Negatif yönlü göçler ise \%88'i İzmir, Antalya, İstanbul, Muğla illerinde kümelenmiştir (Tablo 6). 1990-2000 döneminde Denizli’de toplam net göç miktarı 15.205 kişiye yükselmiştir. Bir önceki döneme göre Denizli’nin net göç miktarı 4.635 kişi artmıştır. Net göç durumunun iller düzeyinde dağılımına bakıldığında; 62 ilde net göç verileri pozitif yönlü iken; 18 ilde negatif 
yönlüdür. Pozitif yönlü göçlerin \%46'sı Afyonkarahisar, Burdur, Şanlıurfa, Uşak, Manisa, Adana, Diyarbakır ve Erzurum illerinde kümelenmiştir. Negatif yönlü göçlerin ise \%84'ü İzmir, Antalya ve Muğla illerine yönelmiştir (Tablo 6).

Şekil 2. Denizli’de İller Arası Net Göçlerin Dağılımı (1975-2018).
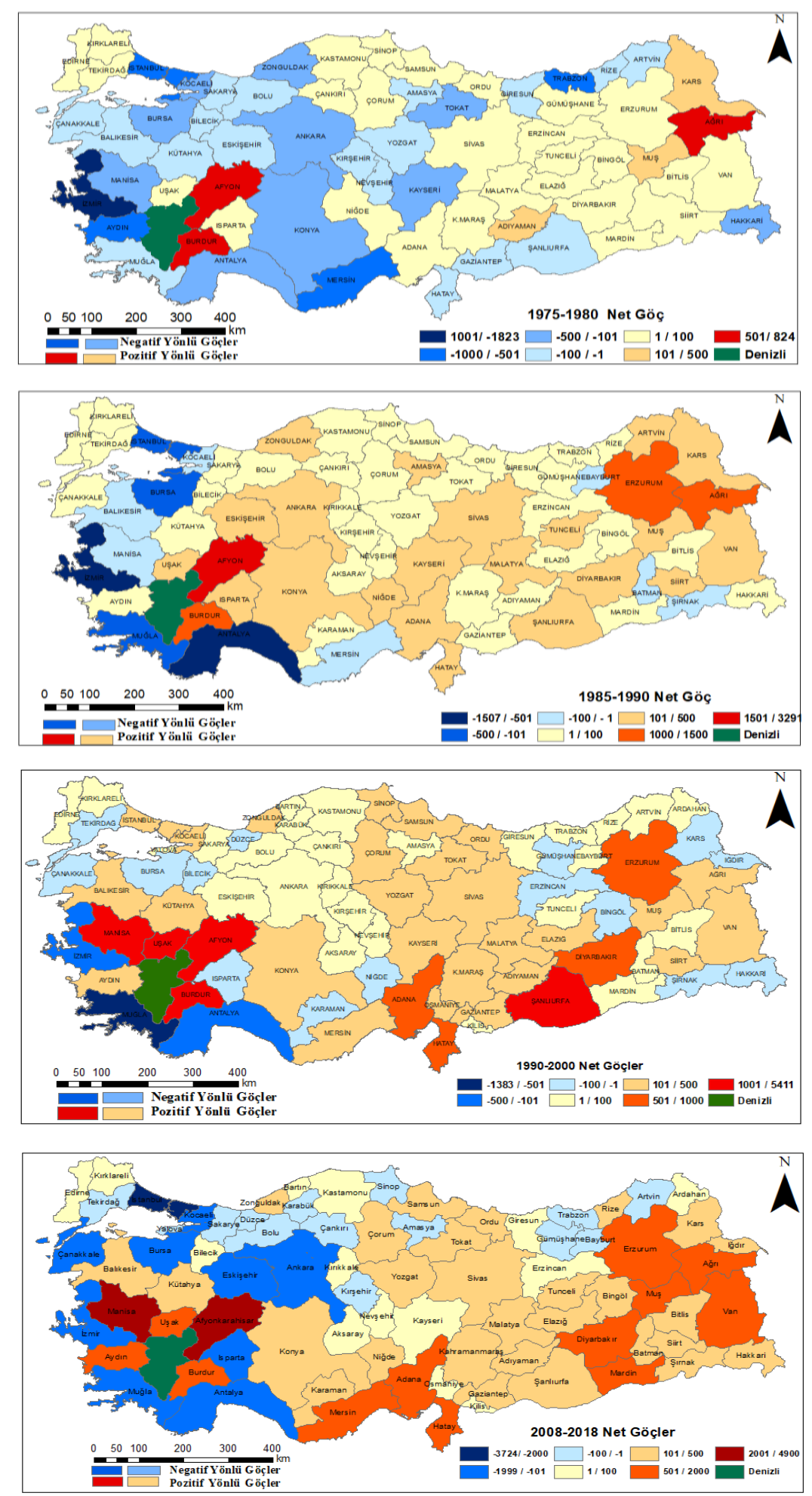

2008-2018 döneminde göç verileri yıl bazında yayımlanmaya başlamıştır. Ancak 2008-2018 yıllarını kapsayan 10 yıllık süreçte Denizli'de göç verileri önceki dönemlerle karşılaştırma yapmak amacıyla bütünleştirilmiştir. Bu dönemde Alınan göçler 283.227'ye çıkarken, verilen göç 266.076'ya çıkmıştır. Net göç miktarındaki artış düşük olsa da alınan göç ve verilen göç miktarı paralel bir şekilde artmıştır. 2008-2018 yıllarını kapsayan 10 yıllık süreçte Denizli'de toplam net göç miktarı ise 17.151 kişiye yükselmiştir. Net göç miktarı düşük olsa da Denizli'de alınan göçler ile verilen göçlerin miktarı oldukça yüksek düzeydedir. Net göç verilerinin iller düzeyinde dağılımına bakıldığında; 56 ilde net göç verileri pozitif yönlü iken, 24 ilde negatif yönlüdür. Pozitif 
GÖKBURUN, İbrahim - Ekonomik Gelişmişliğin Göçler Üzerindeki Etkisi: Denizli Örneği

yönlü göçler \%64'ü Afyonkarahisar, Manisa, Aydın, Van, Erzurum, Ağrı, Uşak, Muş, Adana, Diyarbakır illerinde kümelenmiştir. Negatif yönlü göçlerin ise \%86's1 Ankara, İzmir, Muğla, Antalya, İstanbul ve Eskişehir illerine yöneldiği görülmektedir (Tablo 7).

Tablo 7. Denizli İlinde Net Göç Verilerin Yoğun Olarak Kümelendiği İller (2008-2018)

\begin{tabular}{|c|c|c|c|c|c|c|c|c|c|c|c|}
\hline \multicolumn{12}{|c|}{ Göçlerin Pozitif Yönlü Olduğu İllerde Net Miktarı (2008-2018) } \\
\hline NET & 2008 & NET & 2009 & NET & 2012 & NET & 2013 & NET & 2017 & NET & 2018 \\
\hline Afyonk & 337 & Manisa & 130 & Manisa & 525 & Afyonkarahisar & 868 & Afyonkarahisar & 542 & Erzurum & 183 \\
\hline Ağr1 & 256 & Aydın & 113 & Aydın & 350 & Aydın & 408 & Aydın & 288 & Şanliurfa & 112 \\
\hline Uşak & 250 & Mersin & 88 & Afyonk & 305 & Manisa & 294 & Manisa & 241 & Manisa & 105 \\
\hline Erzurum & 241 & Mardin & 80 & İzmir & 286 & Muğla & 254 & Erzurum & 230 & Ağrı & 82 \\
\hline Burdur & 239 & Malatya & 75 & Bursa & 216 & Ăgrn & 238 & Van & 229 & Uşak & 77 \\
\hline Diyarbakır & 150 & Kars & 58 & Ağn1 & 171 & Erzurum & 228 & Ağr1 & 203 & Balıkesir & 64 \\
\hline Konya & 124 & Sivas & 57 & Erzurum & 168 & Muş & 172 & Muğla & 186 & Gaziantep & 62 \\
\hline Muş & 113 & Adana & 56 & Diyarbakır & 156 & Diyarbakır & 167 & Antalya & 179 & Van & 62 \\
\hline Adana & 83 & Çorum & 43 & Mersin & 149 & Adana & 157 & Gaziantep & 129 & Zonguldak & 55 \\
\hline Van & 79 & Rize & 42 & Muş & 125 & Konya & 118 & Isparta & 111 & Kütahya & 50 \\
\hline Diğer 40 il & 1.181 & Diğer 37 il & 603 & Diğer 42 il & 1.506 & Diğer 45 il & 1.511 & Diğer 54 il & 1.546 & Diğer 36 il & 751 \\
\hline \multicolumn{12}{|c|}{ Göçlerin Negatif Yönlü Olduğu İllerde Net Miktarı (2008-2018) } \\
\hline NET & 2008 & NET & 2009 & NET & 2012 & NET & 2013 & NET & 2017 & NET & 2018 \\
\hline Muğla & -636 & İstanbul & -500 & İstanbul & -275 & İstanbul & -480 & İstanbul & -148 & Afyonk. & -608 \\
\hline Antalya & -460 & Antalya & -446 & Isparta & -200 & Antalya & -157 & Ankara & -82 & Isparta & -308 \\
\hline İstanbul & -350 & İzmir & -435 & Burdur & -167 & Ankara & -124 & Balıkesir & -82 & Muğla & -260 \\
\hline Aydin & -195 & Muğla & -258 & Antalya & -166 & İzmir & -87 & Eskişehir & -50 & İzmir & -204 \\
\hline İzmir & -160 & Isparta & -255 & Ankara & -145 & Eskişehir & -86 & Şırnak & -26 & Ankara & -190 \\
\hline Bursa & -132 & Afyonkarahisar & -197 & Kütahya & -84 & Çanakkale & -85 & Bilecik & -14 & Aydin & -147 \\
\hline Eskişehir & -79 & Ankara & -151 & Çanakkale & -73 & Bursa & -59 & Kastamonu & -13 & Burdur & -109 \\
\hline Gaziantep & -59 & Burdur & -132 & Eskişehir & -67 & Kocaeli & -58 & Yalova & -12 & Bursa & -100 \\
\hline Tekirdağ & -54 & Bursa & -73 & Konya & -49 & Sinop & -36 & Adiyaman & -11 & Çanakkale & -61 \\
\hline Kocaeli & -39 & Eskişehir & -62 & Sakarya & -45 & Karabük & -29 & Amasya & -11 & Kocaeli & -48 \\
\hline Diğer 20 il & -288 & Diğer 23 il & -423 & Diğer 18 il & -232 & Diğer 15 il & -165 & Diğer 7 il & -46 & Diğer 24 il & -427 \\
\hline \multicolumn{12}{|c|}{ TOPLAM NET GÖÇLER MIIKTARI (2008-2018) } \\
\hline 81 İl & 2008 & 81 İl & 2009 & 81 İl & 2012 & 81 İl & 2013 & 81 ìl & 2017 & 81 İl & 2018 \\
\hline Toplam & 601 & Toplam & -1.587 & Toplam & 2.454 & Toplam & 3.049 & Toplam & 3.389 & Toplam & -859 \\
\hline
\end{tabular}

Kaynak: 2008-2018 dönemi TÜİK göç verileri derlenerek yazar tarafindan hazırlanmıştır.

2007-2018 döneminde yıl bazında Denizli'de göçlerin gelişim durumuna bakıldığında; 2008 yılında 601 olan net göç miktarı 2009 yılında -1587 düşerek negatife dönüşmüştür. Eldeki mevcut verilere göre 1980 sonrası dönemde Denizli ili 2009 yılında ilk kez aldığ 1 göçlerden daha çok diğer illere göç vermiştir. 2010 yılında ise net göç miktar1 -1605'e yükselen negatif yönlü göçler 2011 yılında -399'a düşmüştür. 2012 yılında ise net göç miktarı 2.454 kişiye çıkarak pozitife dönüşmüş̧ür. 2015 yılında Denizli'de net göç miktarı artarak 5.224 kişiye yükselmiştir. 2016 yılında Denizli'de net göç miktarı 3.376'ya düşmüştür. 2017 yılında net göç miktarı pozitif olsa da bir önceki yıla göre sadece 13 kişi artmıştır. Bu dönemde Denizli'nin aldığ 1 göçlerde bir düşüş yaşanmaktadır. 2018 yılında ise -859`a düşerek göçler negatife dönüşmüştür (Tablo 2). Bu dönemde yaşanan göçlerdeki dalgalanmanın temel nedeni ekonomik değişkenlerden kaynaklanmıştır.

Göçün itici ve çekici faktörlerinin analizi bakımından 1990 sonrası dönemde kıyaslama imkanı sunan veriler önceki dönemlere göre zenginleşmiştir. Özellikle DPT tarafından yapılan "Illerin ve Bölgelerin Sosyo-Ekonomik 
Gelişmişlik (SEGE) Sıralaması Araştırması" bu verilerden birdir. Sosyo-ekonomik gelişmişlik farklılıklarına göre 5 grup şeklinde sınıflandırılan SEGE, il ve ilçe ölçeğindeki önemli veriler sunmaktadır. SEGE-1996 sıralamasında 76 il arasında 16. bulunan Denizli ili; sınıflamada ikinci derecede gelişmiş iller grubunda yer almaktadır. Birinci derecede gelişmiş iller grubunda; İstanbul, Ankara, İzmir, Kocaeli ve Bursa illeri bulunmaktadır (DPT, 1996:56). İkinci derecede gelişmiş iller grubu; Eskişehir, Kayseri, Tekirdağ, Kırklareli, Balıkesir, Muğla, Aydın, Denizli, Antalya, Adana ve Mersin illerinden oluşan 11 ili kapsamaktadır (DPT, 1996:59). SEGE-2000 sınıflandırmasında ise Denizli, 1996 yılında olduğu gibi ikinci kademe gelişmiş iller grubunda yer almaktadır. Ancak 1996'da SEGE sıralamasına göre 76 il arasından 16. bulunan Denizli; SEGE2003 sıralamasında 12. sıraya yükselmiştir. SEGE-2011 sıralamasına göre ise Denizli 10. sıraya yükselmiştir (DPT, 1996:59; DPT, 2003:83; Kalkınma Bakanlığı, 2013:56). Denizli’nin göç verdiği iller, SEGE sıralamasında birinci kademe gelişmiş iller ve ikinci kademe gelişmiş illerde kümelendiği gözlenmektedir. Buna karşılık Denizli'nin göç aldığı iller ise genel olarak üçüncü derecede gelişmiş iller ve diğer alt kademedeki iller kategorisinde yer almaktadır.

\section{SONUÇ}

Türkiye'de 1950'li yılardan günümüze doğudan batıya, iç kesimlerden kıyılara doğru yoğun bir göç hareketliliği yaşanmaktadır. Ülkenin batısında yer alan Denizli; başta çevre iller olmak üzere doğu ve iç bölgelerdeki illerden yoğun şekilde göç almaktadır. Buna karşılık kıyı ve batı şehirlerine göç vermektedir. Bölgeler arasındaki gelişmişlik farkı bu durumun temel nedenini olarak bilinmektedir. Çalışmamızda elde edilen veriler 1şı̆̆ında Türkiye'de göçlerin yönünü ve miktarını belirleyen faktörler Denizli örnekleminde ortaya konulmuştur. 19201950 döneminde sakin bir süreç yaşayan Denizli, 1950 sonrasında göçlerle hareketlenmeye başlamıştır. Ancak 1975-1980 dönemine kadar Denizli göç veren bir il iken; 1980-1985 dönemi itibariyle göç almaya başlamıştır. 1985-2000 döneminde alınan göçler giderek artmıştır. 2008-2018 döneminde ise Denizli hem göç alan hem de göç veren bir ile dönüşmüştür.

1975-1980 döneminde Denizli’nin net göç hızı \%o-5,7 iken; 1980-1985 döneminde \%o3,5'e yükselmiştir. 19851990 döneminde \%o15,4'e yükselen net göç hızı; 1990-2000 döneminde \%19,8 oranıyla en yüksek seviyeye ulaşmıştır. Bilindiği üzere 2007 yılı itibariyle nüfus verileri yıl bazında açıklanmaktadır. Önceki dönemlerle kıyaslamak amacıyla 2008-2018 dönemini kapsayan 10 y1llık toplam göç verilerinin bütünleştirilmesiyle elde edilen net göç hızı \%17,6'ya düşmüştür. Ancak 2008-2018 döneminde yıl bazında yayımlanan net göç verileri dalgalı bir grafik çizmektedir. Ekonomide yaşanan dalgalanmalar, bu durumun temel sebebi oluşturduğu tespit edilmiştir. Mesela 2008 küresel finansal krizi nedeniyle talepteki azalış sanayi sektöründe üretimde azalışa neden olmuştur. Ekonomideki bu durum istihdam oranlarına yansımıştır. 2007 yılında 148.109 kişi olan istihdam edilen nüfus 2008 yılında 140.506 kişiye düşmüştür. 2009 y1lında ise istihdam sayıs1 134.898'e düşmüştür. Aynı şekilde DSO üye sayısı 2007 yılında 1.287 iken; 2008 yılında 1.205'e düşmüştür. Sonuç olarak bu süreçte Denizli'nin aldığı net göç miktarı düşmüştür. 2010 sonrası dönemde ekonomide yaşana olumlu gelişmeler istihdam oranına yansımıştır. 2012 yılında 166.371 kişi olan istihdam edilen nüfus 2015 yılında 192.244 kişiye yükselmiştir. Buna paralel olarak 2012 yılında \%o2,58'e olan net göç hızı 2015 y1lında \%o5'27'ye yükselmiştir. Nitekim 2012-2015 döneminde alınan göçler artmıştır. 2018 yılında ise net göç hızı \%o-0,84'e düşerken; istihdam edilen nüfus $188.845^{\prime}$ e düşmüştür. 2018 'de DSO üye sayıs1 ise 1.458 'e düşmüştür.

Denizli'nin net göç haritaları incelendiğinde, en çok göç verdiği iller genellikle komşu iller ve büyük şehirlerdir. Denizli'nin yoğun şekilde göç aldığı iller arasında Burdur, Afyonkarahisar, Uşak gibi iç kesimdeki komşu iller bulunmaktadır. Denizli yoğun şekilde göç verdiği İzmir, Aydın, Muğla, Antalya, Bursa gibi gelişmiş kıyı şehirleri bulunmaktadır. Denizli bu şehirlerden aynı şekilde göç almaktadır. Ayrıca, İstanbul ve Ankara alınanverilen göçlerde ön plana çıkmıştır. Ağrı, Erzurum, Van ise öne çıkan diğer illerdir (Şekil 2). 1990 dönemine kadar birkaç ilde yoğunlaşan göçler; 2000 sonrasında yine çevredeki iller başta olmak üzere Türkiye geneline yayılmıştır. Denizli'de göçler illerin sosyoekonomik gelişmişlik durumuna göre yönlenmiştir. Sosyo-Ekonomik Gelişmişlik (SEGE) Sıralamasına göre 2. derecede gelişmiş iller grubunda yer alan Denizli, 1. ve 2. derecede gelişmiş illere göç vermektedir. Buna karşılık 3., 4. ve 5. derecelerde gelişmiş illerden ise göç almaktadır.

1980 sonrasında kentler hiyerarşisinde hızla yükselen Denizli'de sanayi alanında yaşanan gelişmeler; göçlerin yön ve miktarını şekillendirmiştir. Genel anlamda olumsuz bir çağrışım uyandıran göç olgusu; Denizli'de gelişen sanayinin iş gücü ihtiyacını karşılayarak ve üretime dâhil edilip güce dönüşmüştür. Ancak ülkede veya küresel anlamda etkili olan ekonomik ve siyasi gelişmeler Denizli'de göçlerin yönünü ve miktarını şekillendirdiği görülmektedir. Sonuç olarak sanayileşme ve ekonomi alanında yaşanan gelişmeler, bundan sonraki süreçte Denizli'de göçlerin yönünü ve miktarını belirleyecektir. 


\section{KAYNAKÇA}

AKŞITT, Bahattin (1998), "İç Göçlerin Nesnel ve Öznel Toplumsal Tarihi Üzerine Gözlemler: Köy Tarafindan Bir Bakış", Türkiye'de İç Göç: Sorunsal Alanları ve Araştırma Yöntemleri Konferansı Bildiriler Kitabı, 6-8 Haziran 1998 - Gerede/Bolu, Türkiye Ekonomik ve Toplumsal Tarih Vakfı Yayını, İstanbul, ss.22-37.

ALGAN, Neşe (1988), "Adana IIlinde Kentleşme: Kentleşmeyi Etkileyen Faktörler ve Yarattı̆̆ı Sorunlar", Çukurova Üniversitesi İiBF Dergisi, S.2(1), ss.105-119.

ANONIM (2003), Denizli Sanayi Odası Envanteri, Denizli Sanayi Odası Yayınları, Denizli.

ANONIM (2009), Denizli Sanayi Odası İstatistik Yıllı̆̆ı: Rakamlarla Denizli 2009, Denizli Sanayi Odası Yayınları, Denizli.

ANONIM (2013), Denizli Sanayi Odası Stratejik Planı 2014-2016, Denizli Sanayi Odası Yayınları, Denizli.

ANONIM (2018), Denizli Sanayi Odası Stratejik Planı 2019-2023, Denizli Sanayi Odası Yayınları, Denizli.

ANSELIN, Luc ve HUDAK, Sheri (1992), "Spatial Econometrics in Practice: A Review of Software Options", Regional Science And Urban Economics, S.22, ss.509-536.

ANSELIN, Luc (1988), Spatial Econometrics:Methods and Models, Kluwer Academic Publishers, NewYork.

APAN, Ahmet (2006), "Türkiye'de İç Göç Olgusu: Nedenler ve Sonuçlar", Yerel Yönetim ve Denetim Dergisi, S.11(5), ss.26-33.

ATALAY, İbrahim (1994), Türkiye Coğrafyası, Ege Üniversitesi Yayını, İzmir, 4. Baskı.

AYGÖREN, Tulay, GÜMÜŞÇÜ, Osman ve UĞUR, Abdullah (2006), "Daimi İkametgâha Göre Türkiye İ̧ Göçlerinde Denizli İlinin Yeri (1980-2000)", Uluslararası Denizli ve Çevresi Tarih ve Kültür Sempozyumu Bildiriler Kitabı, 6-8 Eylül 2006 - Denizli, ss.326-341.

BAHÇALI, Selin ve ÖZÖZEN, Kahraman (2016), "Artvinlilerin Göç Tercihlerinde Bursa'nın Yerinin Sosyo-Ekonomik ve Mekânsal Analizi", İstanbul Üniversitesi Edebiyat Fakültesi Coğrafya Dergisi, S.33, ss.37-52.

BATMAZ, Nihat (2001), "Gelişimi Üretim Yapısı ve Sorunlarıla Denizli Ekonomisi", Beta Yayınları, İstanbul.

BELGE, Rauf (2018), "Denizli Kent Kimliğini Oluşturan Coğrafi Öğeler", Ege Coğrafya Dergisi, S.27(2), ss.167-181.

BÜLBÜL, Serpil ve KÖSE, Ali (2010), "Türkiye'de Bölgelerarası Iç Göç Hareketlerinin Çok Boyutlu Ölçekleme Yöntemi Ile İncelenmesi", İstanbul Üniversitesi İşletme Fakültesi Dergisi, S.39(1), ss.75-94.

CERİT, Sevil (1986), "Türkiye'de Iller Arası Göçler (1950-1980)", Nüfus Bilim Dergisi (The Turkish Journal of Population Studies), S.8, ss.81-103.

ÇELIK, Fatih (2005), "Iç Göçler: Teorik Bir Analiz", Çukurova Üniversitesi Sosyal Bilimler Enstitüsü Dergisi, S.14(2), ss.167-184.

ÇELIK, Fatih (2006), "İç Göçlerin İtici ve Çekici Güçler Yaklaşımı İle Analizi", Erciyes Üniversitesi İktisadi ve İdari Bilimler Fakültesi Dergisi, S.27, ss.149-170.

ÇELIK, Fatih (2007), "Türkiye'de İ̧̧ Göçler 1980-2000", Erciyes Üniversitesi Sosyal Bilimler Fakültesi Dergisi, S.22(1), ss.87-109.

ÇELIK, Nermin ve GÜVEN, Murat (2014), "Türkiye'de Iç Göç Sorununa Yeni Bir Yaklaşım: Stratejik Iç Göç Yönetimi", İstanbul Üniversitesi İşletme İktisadi Enstitüsü Yönetim Dergisi, S.76, ss.45-61.

ÇİFTÇİ, Murat (2011), "Bölgeler Arası Eşitsizlik Perspektifiyle İç Göç-Sosyoekonomik Gelişmişlik İlişkisi ve Türkiye Örneği", Yayımlanmamış Doktora Tezi, Yıldız Teknik Üniversitesi Fen Bilimleri Enstitüsü, İstanbul.

DARKOT, Besim (1954), "Türkiye'de Nüfus Hareketleri", İstanbul Üniversitesi Coğrafya Enstitüsü Dergisi, S.5-6, ss.3-22. 
DARKOT, Besim (1961), "Türkiye'nin Nüfus Hareketlen Üzerine Yeni Gözlemler", Türk Coğrafya Dergisi, S.21, ss.1-14.

DOĞAN, Mesut (2019). “Türkiye'nin Ticaret Coğrafyası”, Türkiye Beşeri ve İktisadi Coğrafyası (Ed: Taşııil, N. ve Şahin, G.,), Nobel Akademik Yayıncılık, Ankara. ss.271-347.

DOĞANAY, Hayati (1986), "Trabzon İlinde Nüfus Hareketleri ve Göçler", Atatürk Üniversitesi FenEdebiyat Fakültesi Araştırma Dergisi, S.15(2), ss.281-305.

DOĞANAY, Hayati (1994), Türkiye Beşeri Coğrafyası, Gazi Büro Kitabevi, Ankara.

DOH, Re-Mee (1984), "Interprovincial Migration in Turkey And Its SocioEconomic Background: A Correlation Analysis", Nüfus Bilim Dergisi, S.6, ss.49-61.

DPT (1996), İllerin Sosyo-Ekonomik Gelişmişlik Sıralaması Araştırması, DPT Yayınları, Ankara.

DPT (2003), İllerin ve Bölgelerin Sosyo-Ekonomik Gelişmişlik Sıralaması Araştırması, DPT Yayınları, Ankara.

ELMASTAŞ, Necmettin ve YILMAZ, Süleyman (2015), "Van Ilinde Göçler", Turkish Studies, S.10(10), ss.403-428.

ENGIN, Cem ve GÖLLÜCE, Esra (2016), "2008 Küresel Finans Krizi ve Türkiye Üzerine Yansımaları", Kahramanmaraş Sütçü İmam Üniversitesi İïBF Dergisi, S.6(1), ss.27-40.

ERAYDIN, Ayda (1981), Türkiye'de 1950-1980 Döneminde İler Arası Göçlerin Genel Değerlendirilmesi, DPT Yayınları, Ankara.

PALAZ ERDEMIR, Hatice (2007), "Antikçağ'da Hierapolis ve Çevresinde Koyun Yetistiriciliği ve Yan Sektörleri", Uluslararası Denizli ve Çevresi Tarih ve Kültür Sempozyumu Bildiriler Kitabı, 6-8 Eylül 2006 - Denizli, ss.23-30.

ERDOĞMUŞ, Zeki (1989), "Türkiye'de Kırdan Kente Göçün Sosyal Temelleri", Frrat Üniversitesi Sosyal Bilimler Dergisi, S.3(2), ss.97-108.

EREL, Levent (1985), "Antalya İlinde 1935-1980 Yilları Arasındaki Devrede Nüfus Hareketleri", İstanbul Üniversitesi Coğrafya Bölümü Dergisi, S.1, ss.191-201.

ERTÜRK, Emin (1985), "Göçün Ekonomik Analizi", Uludağ Üniversitesi İïBF Dergisi, S.6(2), ss.1-9.

GEDIK, Ayşe (1994), Türkiye’de İç Göçler 1965-85: Bazı Varsayımların Sorgulanması, ODTÜ Mimarlık Fakültesi Yayını, Ankara.

GEDİK, Ayşe (1985), "Rural to Urban Versus Urban to Urban Migration in Turkey, 1965-70", EspacePopulations-Societies, S.1, ss.86-92.

GÖKBURUN, İbrahim (2017)," İstanbul'da Nüfus Hareketleri: 1950-2015", Yayımlanmamış Doktora Tezi, İstanbul Üniversitesi Sosyal Bilimleri Enstitüsü, İstanbul.

GÜR, Timur Han ve URAL, Emel (2004), "Türkiye'de Kentlere Göçün Nedenleri", Hacettepe Üniversitesi İktisadi ve İdari Bilimler Fakültesi Dergisi, S.22(1), ss.23-38.

GÜZEL, Serkan (2013), "Göçmen Çocuklar ve Denizli'de Yaşam Koşulları", Hacettepe Üniversitesi Sosyolojik Araştırmalar Dergisi, S.51, ss.1-36.

IŞIK, Şevket (1999), "İzmir'e Yönelik Göçlerin Coğrafi Boyutları", Türk Coğrafya Dergisi, S.34, ss.383-405.

IŞIK, Şevket (2009), "1995-2000 Döneminde İmir'e Yönelik Göçler", Türk Coğrafya Dergisi, S.52, ss.9-16.

İÇDUYGU, Ahmet ve SİRKECI,, İbrahim (1999), "Cumhuriyet Dönemi Türkiye'sinde Göç Hareketleri", 75 Yılda Köylerden Şehirlere (Ed. Oya Baydar), Tarih Vakfı Yayınları, İstanbul, ss.249-268.

İÇDUYGU, Ahmet, SİRKECI, İbrahim ve AYDINGÜN, İsmail (1998), "Türkiye'de İç Göç ve İç Göçün İşçi Hareketlerine Etkisi", Türkiye'de İç Göç (Ed.Ahmet İçduygu), Tarih Vakfı Yayını, İstanbul, ss.207-244.

İÇDUYGU, Ahmet ve ÜNALAN, Turgay (1998), "Türkiye'de İç Göç: Sorunsal Alanları ve Araştırma Yöntemleri", Türkiye'de İç Göç, Sorunsal Alanları ve Araştırma Yöntemleri Konferansı Bildiriler Kitabı, 6-8 Haziran 1998 - Gerede/Bolu, Türkiye Ekonomik ve Toplumsal Tarih Vakfı Yayını, İstanbul, ss.38-55. 
DİNÇ, Abdurrahman (2014), "Daimi İkametgâha Göre Türkiye İç Göçlerinde Konya İlinin Yeri (1980-2013)", Sosyal Ekonomik Araştırmalar Dergisi, S.14(28), ss.1-33.

KALKINMA BAKANLIĞI (2013), İllerin ve Bölgelerin Sosyo-ekonomik Gelişmişlik Sıralaması Araştırması, Kalkınma Bakanlığı Yayınları, Ankara.

KARA, Hasan (2008), "Denizli Şehrinde Gecekondulaşmanın Önlenmesi ve Toplu Konutlar", Doğu Coğrafya Dergisi, S.23, ss.103-118.

KARAALP, H. Simay (2004), "Sanayileşmeye Etki Eden Faktörler ve Denizli Sanayinin Yerleşimi", Yayımlanmamış Yüksek Lisans Tezi, Pamukkale Üniversitesi Sosyal Bilimler Enstitüsü, Denizli.

KARAL, Enver Ziya (1997), Osmanlı İmparatorluğu'nda İlk Nüfus Sayımı, DİE Yayını, Ankara.

KARPAT, Kemal H. (2003), Osmanlı Nüfusu (1830-1914) Demografik ve Sosyal Özellikleri, TVYY, İstanbul.

KARPAT, Kemal H. (2015), Türkiye’nin Göç Tarihi: 14. Yüzyıldan 21. Yüzyıla Türkiye’ye Göçler, İstanbul Bilgi Üniversitesi Yayınları, İstanbul.

KELEŞ, Zülal (2007), "1923-1945 Yılları Arasında Denizli’ye İç ve Dış Göçler", Uluslararası Denizli ve Çevresi Tarihi ve Kültürü Sempozyumu Bildiriler Kitabı, Pamukkale Üniversitesi Fen-Edebiyat Fakültesi Yayın1, Denizli, ss.290-301.

KOCAMAN, Sinan (2014), "Kentsel Alanlara Göç Eden Kırsal Nüfusun Kentsel Uyumu ve Kentlileşme Düzeyi Üzerine Uygulamalı Bir Araştırma: A ̈̆rı Örneği", Uluslararası Sosyal Araştırmalar Dergisi, S.7(34), ss.335-349.

KOCAMAN, Tuncer (2008), Türkiye'de İç Göçler ve Göç Edenlerin Nitelikleri (1965-2000), DPT Yayını, Ankara.

KOCAMAN, Tuncer ve BAYAZIT, Sema (1993), Türkiye'de İç Göçler ve Göç Edenlerin Sosyo-Ekonomik Nitelikleri, DPT Sosyal Planlama Genel Müdürlüğ̈̈ Yayını, Ankara.

KOÇAK, Yüksel ve TERZİ, Elvan (2012), "Türkiye'de Göç Olgusu, Göç Edenlerin Kentlere Olan Etkileri ve Çözüm Önerileri", Kafkas Üniversitesi İktisadi ve İdari Bilimler Fakültesi Dergisi, S.3(3), ss.163-184.

KODAL, Tahir (2014), Cumhuriyet Döneminde Denizli-Honaz’da Nüfus (1923-2013), Denizli Büyükşehir Belediyesi Kültür Yayını, Denizli.

KÜÇÜKALİ, Adnan (2016), Bir Sosyal Politika Problemi Olarak Göç: Erzurum Örneği, İmaj Yayınevi, Ankara.

LEE, Everett S. (1966), "A Theory of Migration", Demography, S.3(1), ss.47-57.

LEE, Everett S. (1969), "A Theory of Migration, Migration (Der. J. A. Jackson), Cambridge University Press, Great Britain, ss.283-297.

LEWIS, Graeme John (1982), Human Migration: A Geographical Perspective, St. Martin's Press, NewYork.

MUTLUER, Mustafa (2003), Uluslararası Göçler ve Türkiye, Çantay Kitabevi, İstanbul.

MUTLUER, Mustafa (2003), "Türkiye'de Yeni Sanayileşme Odakları: Denizli - Gaziantep - Çorum", Ege Coğrafya Dergisi, S.12(1), ss.13-28.

OKAY, Şenol ve KARAHAN, Mehmet (2012), "Denizli Sanayi Işsletmelerinde 2008 Küresel Ekonomik Krizinin Etkileri Üzerine Bir Alan Araştırması", KEV Akademi Dergisi, S.16(50), ss.299-316.

OKTIK, Nurgün (1997), "Köyün İticiliği Kentin Çekiciliği", Toplum ve Göç Bildirileri Kitabı, DİE Yayını, Ankara, ss.81-85.

ÖZATAY, Fatih (2009), Finansal Krizler ve Türkiye, Doğan Kitap Yayınları, İstanbul.

ÖZDEMİR, Hakan (2012), "Türkiye'de İç Göçler Üzerine Genel Bir Değerlendirme", Akademik Bakış Dergisi, S.30, ss.1-18.

ÖZDEMİR, Murat (2006), "Türkiye'de İç Göç Olgusu, Nedenleri ve Çorlu Örneği", Yayımlanmamış Yüksek Lisans Tezi, Trakya Üniversitesi Sosyal Bilimler Enstitüsü, Edirne.. 
ÖZGÜR, Ertuğrul Murat (1995), "Türkiye'deki İç Göçlerde Ankara İlinin Yeri", Ankara Üniversitesi Türkiye Coğrafyası Araştırma ve Uygulama Merkezi Dergisi, S.4, ss.63-76.

ÖZGÜR, Ertuğrul Murat (1999), "Türkiye'de Il İçi Göçler Hakkında Düşünceller", Ankara Üniversitesi Dil ve Tarih Coğrafya Fakültesi Dergisi, S.39(1-2), ss.159-167.

ÖZGÜR, E. Murat ve YASAK, Üzeyir (2009), "Şehir İçi İkametgah Hareketliliğine Kuramsal Bir Baklş", Coğrafi Bilimler Dergisi, S.7(1), ss.39-50.

ÖZTÜRK, Serdar ve GÖVDERE, Bekir (2010), "Küresel Finansal Kriz ve Türkiye Ekonomisine Etkileri", Süleyman Demirel Üniversitesi İktisadi ve İdari Bilimler Fakültesi Dergisi, S.15(1), ss.377-397.

PAZARLIOĞLU, M. Vedat (2007), "İzmir Örneğinde Iç Göçün Ekonometrik Analizi", Yönetim ve Ekonomi Dergisi, S.14(1), ss.121-135.

PEKER, Mümtaz (1999), "Türkiye'de İç Göçün Değişen Yapısı", 75 Yılda Köylerden Şehirlere, Tarih Vakfı Yayınları, İstanbul, ss.295-304,

PEKER, Mümtaz (2015), Sahil Kasabasından Büyükşehire Evrimleşme Sürecinde İzmir’e Göç, İzmir Büyükşsehir Belediyesi Yayınları, İzmir.

PERRUCHOUD, Richard ve REDPATH-CROSS, Jilyanne (2009), Uluslararası Göç Hukuku Göç Terimleri Sözlüğü, Uluslararası Göç Örgütü Yayını, İsviçre, 2. Baskı.

RAVENSTEIN, Ernest George (1885), "The Laws of Migration", Journal of The Statistical Society of London, S.48(2), ss.167-227.

RAVENSTEIN, Ernest George (1889), "The Laws of Migration", Journal of The Statistical Society, S.52, ss.214-301.

SAĞLAM, Serdar (2006), "Türkiye'de Iç Göç Olgusu ve Kentleşme", Türkiyat Araştırmaları Dergisi, S.5, ss.34-44.

STOUFFER, Samuel A. (1940), "Intervening Opportunities: A Theory Relating Mobilityand Distance", American Sociological Review, S.5(6), ss.845-867.

SERTKAYA DOĞAN, Özlem (2015), Biga Yarımadası Nüfus Coğrafyası, Yeni Anadolu Yayınları, İstanbul.

ŞAHIN, Cemalettin (2005), "İstanbul'a Olan İç Göçlerde Denizli İlinin Yeri ve Göçle Gelen Nüfusun Özellikleri", Uluslararası Denizli ve Çevresi Tarih ve Kültür Sempozyumu Bildiriler Kitabı, 6-8 Eylül - Denizli, Pamukkale Üniversitesi Fen Edebiyat Fakültesi Yayını, 2 Cilt.

ŞANLI, Cennet ve KARA, Hasan (2019), "Determinatıon of Thermal Tourısm Potentıal in Karahayıt, Denızlı: A Study on Local Tourtsts", International Journal of Geography And Geography Education, S.40, ss.266-282.

ŞENSOY, Sefer Eyüp (2005), "Kent ve Göç Van Illine Çevre Il ve İlçelerden Göç Edenlerin Sorunlarına Sosyolojik Bir Yaklaşım", Yayımlanmamış Yüksek Lisans Tezi, Van Yüzüncü Yıl Üniversitesi Sosyal Bilimler Enstitüsü, Van.

TANDOĞAN, Alaattin (1989a), "Türkiye Nüfus Hareketlerinde İstanbul'un Yeri", Coğrafya Araştırmaları Dergisi, S.1(1), ss.135-141.

TANDOĞAN, Alaattin (1989b), Türkiye'de 1975-1980 Döneminde İller Arası Göçler, Karadeniz Teknik Üniversitesi Yayınları, Trabzon.

TEKELİ, İlhan (1997), "Türkiye'de İç Göç Sorunsalı Yeniden Tanımlanma Aşamasına Geldi", Türkiye'de İç Göç: Sorunsal Alanları ve Araştırma Yöntemleri Konferansı Bildiriler Kitabı, Tarih Vakfı Yayınları, 6-8 Haziran - Gerede/Bolu, ss.7-21.

TEKELİ, İlhan (1998), "Türkiye'de İç Göç Sorunsalı Yeniden Tanımlanma Aşamasına Geldi", Türkiye'de İç Göç: Sorunsal Alanları ve Araştırma Yöntemleri Konferansı Bildiriler Kitabı, Tarih Vakfı Yayınları, 6-8 Haziran - Gerede/Bolu, ss.7-21.

TEMEL, Adil, ÖZEREN, Suat, ULU, Rahmi ve BOYAR, Ercan (2002), Denizli ve Gaziantep İlleri İmalat Sanayinin Yapısı, DPT Ekonomik Modeller ve Stratejik Araştırmalar Genel Müdürlüğü Yayını, Ankara. 
TOBLER, Waldo R. (1970), "A Computer Movie Simulating Urban Growth in The Detroit Region", Economic Geography, S.46(2), ss.234-240.

TORLAK, Sülün Evinç ve POLAT, Ferihan (2006), "Kentleşme Sürecinde Kimlik Farklllaşması Açısından Denizli’de İki Mahallenin Karşılaştırmalı Analizi", Gazi Üniversitesi İïBF Dergisi, S.8(2), ss.167-186.

TOROĞLU, Emin (2007), "Niğde İlinde Göç Faktörleri ve Göçler", Coğrafi Bilimler Dergisi, S.5(1), ss.75-96.

TÜMERTEKIN, Erol (1968), Türkiye'de İç Göçler, İstanbul Üniversitesi Yayınları, İstanbul.

TÜMERTEKIN, Erol (1972), "Türkiye'de Kademeli Göçler", Sosyal Antropoloji ve Etnoloji Dergisi, S.1, ss.47-86.

TÜMERTEKİN, Erol (1977a), "Türkiye'de İ̧̧ Göçlerde Yeni Eğilimler", Şehircilik Enstitüsü Dergisi, S.14, ss.18-33.

TÜMERTEKIN, Erol (1977b), "Türkiye'de İç Göçler Üzerine", İstanbul Üniversitesi Coğrafya Enstitüsü Dergisi, S.22, ss.29-42.

TÜMERTEKİN, Erol ve ÖZGÜÇ, Nazmiye (2017), Beşeri Coğrafya İnsan, Kültür, Mekan, Çantay Yayınları, İstanbul.

USLU, Levent (2012), "Göçmenlerde Yoksulluk Yansımaları: Denizli Örneği", Yüksek Lisans Tezi, Pamukkale Üniversitesi Sosyal Bilimler Enstitüsü, Denizli.

ÜÇDOĞRUK, Şenay (2002), "İzmir'de İç Göç Hareketlerinin Çok Durumlu Logit Tekniklerle İncelenmesi", Dokuz Eylül Üniversitesi IIIBF Dergisi, S.17(1), ss.157-183.

ÜNLÜTÜRK ULUTAŞ, Çağla ve KAMBER, Asiye (2017), "İç Göç ve Mekânsal Dışlanma", Anadolu Üniversitesi Sosyal Bilimler Dergisi, S.17(4), ss.1-14.

YAKAR, Mustafa ve SERT ETEMAN, Fatma (2017), "Türkiye'de İller Arası Göçlerin Nodexl İle Sosyal A ̆g Analizi", Göç Dergisi, S.4(1), ss.82-109.

YAKAR, Mustafa (2009a), "İller Arası ve İ İçi Göçlerde Afyonkarahisar Kenti (1975-2000)", Afyon Kocatepe Üniversitesi SBE Dergisi, S.10(1), S.141-163.

YAKAR, Mustafa (2009b), "İller Arası Göçlerde Afyonkarahisar İli", Afyon Kocatepe Üniversitesi Sosyal Bilimler Dergisi, S.11(2), ss.21-48.

YAKAR, Mustafa (2012), "Türkiye'de İç Göçlerin İlçelere Göre Mekânsal Analizi: 1995-2000 Dönemi", Uluslararası İnsan Bilimleri Dergisi, S.9(1), ss.741-768.

YAKAR, Mustafa (2013), "Türkiye'de İller Arası Net Göçlerle Sosyo-Ekonomik Gelişmişlik Arasındaki İlişsinin Coğrafi Ağırlıklı Regresyon ile Analizi", Ege Coğrafya Dergisi, S.22(1), ss.27-43.

YAKAR, Mustafa (2015), "Türkiye’nin İç Göç Paterni: Kim Nerede Ikamet Ediyor? Nereye Kayıtll", Ege Coğrafya Dergisi, S.24(1), ss.15-38.

YAKAR, Mustafa, SARAÇLI, Sinan ve YAZICI, Hakkı (2010), "Afyonkarahisar İlinde İller Arası Göçlerin Gelişmişlik Endeksleriyle Analizi”, Doğu Coğrafya Dergisi, S.15(24), ss.255-271.

YALÇIN, Cemal (2004), Göç Sosyolojisi, Anı Yayıncılık, Ankara.

YAMAK, Rahmi ve YAMAK, Nebiye (1999), "Türkiye'de Gelir Dağılımı ve İç Göç", Dokuz Eylül Üniversitesi Sosyal Bilimler Enstitü Dergisi, S.1(1), ss.16-28.

YASA, İbrahim (1968), "İç Göçlerin Büyük Şehirlerin İş-Güç Çeşitlerindeki Etkileri (Ankara Örneği)", AÜEF Dergisi, S.1(1-4), ss.175-193.

YAVUZ, Orhan (1994), "Erzurum'dan Göç Sorunu, Nedenleri, Sonuçları ve Çözüm Yolları", Tarım Ekonomisi Dergisi, S.2, ss.10-21.

YENER, Samira (1977), 1965-1970 Döneminde İller Arası Göçler ve Göç Edenlerin Nitelikleri, DPT Yayın1, Ankara.

YÜCEŞAHIN, M. Murat, ve ÖZGÜR, E. Murat (2006), "Türkiye'nin Güneydoğusunda Nüfusun Zorunlu Yerinden Oluşu: Süreçler ve Mekansal Örüntü", Coğrafi Bilimler Dergisi, S.4(2), ss.15-35. 